\title{
A review of the anthropogenic influence on biogenic secondary organic aerosol
}

\author{
C. R. Hoyle ${ }^{1,2}$, M. Boy ${ }^{3}$, N. M. Donahue ${ }^{4}$, J. L. Fry ${ }^{5}$, M. Glasius ${ }^{6}$, A. Guenther ${ }^{7}$, A. G. Hallar ${ }^{8}$, K. Huff Hartz ${ }^{9}$, \\ M. D. Petters ${ }^{12}$, T. Petäjä ${ }^{3}$, T. Rosenoern ${ }^{11}$, and A. P. Sullivan ${ }^{10}$ \\ ${ }^{1}$ Institute for Atmospheric and Climate Science, ETH Zurich, Switzerland \\ ${ }^{2}$ Department of Geosciences, University of Oslo, Norway \\ ${ }^{3}$ Department of Physics, University of Helsinki, P.O. Box 64, 00048 Helsinki, Finland \\ ${ }^{4}$ Carnegie Mellon University, Center for Atmospheric Particle Studies, Pittsburgh, PA 15213, USA \\ ${ }^{5}$ Chemistry Department, Reed College, Portland, OR, 97202, USA \\ ${ }^{6}$ Department of Chemistry, Aarhus University, 8000 Aarhus C, Denmark \\ ${ }^{7}$ National Center for Atmospheric Research, P.O. Box 3000, Boulder, CO, USA \\ ${ }^{8}$ Desert Research Institute, Storm Peak Laboratory, P.O. Box 882530, Steamboat Springs, Colorado, USA \\ ${ }^{9}$ Department of Chemistry \& Biochemistry, 224 Neckers Hall, Southern Illinois University, Carbondale, IL 62901, USA \\ ${ }^{10}$ Colorado State University, Department of Atmospheric Science, Fort Collins, CO 80523, USA \\ ${ }^{11}$ Environmental Chemistry, Engineering Sciences Lab 230, Harvard, Cambridge, MA 02138, USA \\ ${ }^{12}$ North Carolina State University, Marine Earth and Atmospheric Sciences, Raleigh, NC 27695, USA
}

Received: 10 August 2010 - Published in Atmos. Chem. Phys. Discuss.: 19 August 2010

Revised: 2 December 2010 - Accepted: 2 January 2011 - Published: 14 January 2011

\begin{abstract}
Because of the climate and air quality effects of organic aerosol, it is important to quantify the influence of anthropogenic emissions on the aerosol burden, both globally and regionally, and both in terms of mass and number. Methods exist with which the fractions of organic aerosol resulting directly from anthropogenic and biogenic processes can be estimated. However, anthropogenic emissions can also lead to an enhancement in secondary organic aerosol formation from naturally emitted precursors. We term this enhanced biogenic secondary organic aerosol (eBSOA). Here, we review the mechanisms through which such an effect may occur in the atmosphere and describe a work flow via which it may be quantified, using existing measurement techniques. An examination of published data reveals support for the existence of the enhancement effect.
\end{abstract}

\section{Introduction}

Organic material can comprise a significant fraction of particulate aerosol mass at urban and remote locations (e.g. Chow et al., 1994; Malm et al., 1994; Andrews et al., 2000;

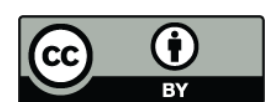

Correspondence to: C. R. Hoyle (christopher.hoyle@env.ethz.ch)
Kanakidou et al., 2005; Zhang et al., 2007a; Jimenez et al., 2009). The last decade saw significant improvements in the characterisation of organic aerosols and the understanding of their sources and impacts on the environment. This research has provided insight into the contribution of organics to fine particulate matter, and thus potentially negative health effects (Ostro and Chestnut, 1998). Organic aerosols play an important role in the climate system. They affect the Earth's radiation balance directly by scattering sunlight, but also indirectly through their role as cloud condensation nuclei (CCN) (Twomey, 1974; Twomey et al., 1984; Albrecht, 1989; Charlson et al., 1992; Chuang et al., 1997; Adams et al., 2001; Hansen and Sato, 2001; Schulz et al., 2006). Further, the presence of organic species in atmospheric aerosol can affect the hygroscopicity and the ability of internally mixed aerosol particles to serve as CCN (Corrigan and Novakov, 1999; Prenni et al., 2001; Giebl et al., 2002; Raymond and Pandis, 2002; Pradeep Kumar et al., 2003; Prenni et al., 2003; Merikanto et al., 2009).

The role of organic aerosols in visibility-reducing haze on the regional scale (e.g. Tanner, 2000) has also been examined. Because of the effects of organic aerosols on air quality and climate, it is desirable to separate the anthropogenic contribution from the natural background, to guide future regulatory measures that may be implemented in order to lower emissions contributing to the organic aerosol

Published by Copernicus Publications on behalf of the European Geosciences Union. 
burden. Usually, regulation targets the control of various kinds of emissions such as SOA precursors, nitrogen oxides $\left(\mathrm{NO}_{\mathrm{x}}\right)$, particulate matter mass, or sulphate mass. Before implementing emission controls, chemistry models at a range of scales are used to assess the effect of changes in emissions on the organic aerosol burden. In large scale chemical transport models, organic aerosols have commonly been classified in two groups; essentially non-volatile species emitted as aerosols (primary organic aerosol, or POA), and the volatile compounds which oxidise and then partition to the condensed phase in the atmosphere (secondary organic aerosol, or SOA) (e.g. Chung and Seinfeld, 2002; Tsigaridis and Kanakidou, 2003; Hoyle et al., 2007). Recently, POA has been shown to be, if anything, more volatile than SOA (Robinson et al., 2007; Huffman et al., 2009), but the designation of POA as un-reacted and generally reduced primary emissions is still valid (Donahue et al., 2009). Starting from an experimental point of view, Fuzzi et al. (2006) introduced a source-based classification of anthropogenic POA (APOA) and anthropogenic SOA (ASOA) and proposed a set of measurable distinguishing characteristics of the carbonaceous particles in these groups. It should be noted that these definitions and the measured masses depend on the measurement techniques applied, and that as measurement techniques are changed or improved, new sub categories of $\mathrm{OA}$ are often defined. Not all organic species can be detected or analysed by the various techniques available.

Sources of anthropogenic OA include not only aerosol mass from fossil fuel combustion, but also from meat cooking, biomass burning, the use of biofuels, and other human activities that lead to the emission of both fossil and modern (i.e. not fossil) volatile organic carbon. Consequently, one must separate modern OA into biogenic and anthropogenic fractions. However, even determining a fraction of modern VOC that is actually emitted through anthropogenic activities does not capture the whole human influence on the organic aerosol budget, as it ignores any possible enhancement, through anthropogenically emitted compounds, of SOA formation from true biogenic precursors.

In this paper we summarise the various feedbacks between anthropogenic activities and BSOA formation, and we describe methods for separating SOA due to the different sources. In Sect. 2 we discuss the mechanisms through which anthropogenic emissions may influence the formation of SOA from naturally emitted precursors. Section 3 presents the various methods which are used to attribute observed organic aerosol to a source, while in Sect. 4 we discuss the available observations that are suitable for detecting the enhancement effect. Section 5 presents a summary and conclusions.

\section{Mechanisms for an anthropogenic effect on BSOA}

\subsection{Partitioning}

In the atmosphere, biogenic volatile organic compounds (BVOC) molecules react with $\mathrm{OH}, \mathrm{O}_{3}$ or $\mathrm{NO}_{3}$ to form more functionalized molecules. These reaction products form a distribution in volatility space, with some being able to reversibly partition into the condensed phase. Observations of organic mass loading dependent aerosol yield are generally modelled using equilibrium gas/particle partitioning (Pankow, 1994; Odum et al., 1996; Donahue et al., 2006b), and observations often show lower yields under conditions with low organic aerosol loadings $\left(0.1-1 \mu \mathrm{g} \mathrm{m}^{-3}\right)$. Any process that increases organic aerosol mass loading (e.g. anthropogenic SOA or POA) should then, in principle, result in increased BVOC yields. This reasoning implicitly assumes that the aerosol forms a well-mixed liquid phase containing a myriad of mutually miscible organic compounds, and that dissolution of organic vapours in a pre-existing organic liquid will increase the equilibrium uptake of the reacted BVOC products (Seinfeld and Pankow, 2003; Kroll and Seinfeld, 2008). The overall uptake depends on the miscibility and activity coefficients of the semi-volatile compounds. Thus, if BSOA is miscible in pre-existing organic aerosol from anthropogenic activity, it should in principle enhance the incorporation of BVOC oxidation products into the condensed phase.

Defining the properties of "anthropogenically derived organic aerosol" is difficult, as it can be soot, primary organic aerosol from combustion (e.g. meat cooking or diesel exhaust), or SOA from the oxidation of anthropogenic VOCs. Generally seen, soot is primarily composed of carbon in its elemental form (Seinfeld and Pandis, 1998), POA is composed of elemental carbon, linear, cyclic and branched hydrocarbons with oxygenated carbons and large carbon numbers $\left(\mathrm{C}_{18}-\mathrm{C}_{40}\right)$ (Sakurai et al., 2003; Behera and Sharma, 2010), and SOA is composed of highly functionalized molecules with relatively short carbon chains (typical molecular weights $<500 \mathrm{Da}$, assuming a typical C:O ratio $\sim 0.4$, molecules have carbon numbers $<\mathrm{C}_{15}$ ) (Baltensperger et al., 2005). Clearly, the partitioning of BVOCs in these different types of anthropogenic organic aerosol will depend on the particle composition and phase, as well as changes in these properties with particle age. Song et al. (2007) and AsaAwuku et al. (2009) found that model POA hydrocarbons do not form a miscible phase with monoterpene SOA, suggesting no anthropogenic enhancement effect. However, AsaAwuku et al. (2009) found the opposite for diesel exhaust particles. Further, to our knowledge, there are no studies testing the effect of incorporation of BVOC products in SOA from anthropogenic precursors or chemically aged POA. Since these compounds are more oxidised, and hence more similar to BVOC oxidation products, enhancement effects due to partitioning are plausible and should be investigated further. 
Water may also contribute to the organic phase and generally increases partitioning into the condensed phase (Seinfeld et al., 2001). The presence of water also causes repartitioning due to preferential uptake of more polar compounds while simultaneously driving less polar compounds into the gas phase (Seinfeld and Pankow, 2003). Chamber studies suggest that the water uptake behaviour of SOA generated from biogenic and anthropogenic precursors is generally similar (Baltensperger et al., 2005; Varutbangkul et al., 2006; Prenni et al., 2007) and thus differences in organic aerosol water uptake are unlikely to result in major differences in partitioning between urban and rural areas. These studies, however, cannot distinguish between a single aqueous-organic phase and a mixture containing an aqueous-organic and liquid pure organic phase. Therefore, the hygroscopicity measurements do not necessarily suggest that anthropogenic and biogenic organic aqueous solutions result in the same degree of repartitioning of polar and non-polar compounds. Furthermore, the role of inorganic water uptake, which exceeds that of most organic compounds (Petters and Kreidenweis, 2007), is unclear. Initial experiments by Prisle et al. (2010) suggest that partitioning enhancement due to inorganically bound water is modest for fresh $\alpha$-pinene-derived SOA at atmospherically relevant mass concentrations, but more data are needed to establish the generality of this finding. In particular, the enhancement depends on the solubility of the organic compounds in water. There is a clear need for more data including systems that produce more oxidised compounds (e.g. SOA from isoprene), more water soluble compounds (e.g. aged SOA), and more high vapour pressure but water soluble compounds (e.g. glyoxal).

The preceding discussion highlights the importance of both aerosol mixing state and single particle phase state of the organic compounds. The assumption of a well-mixed organic phase with little or no water present is likely correct in controlled chamber experiments, and may also be correct far from point sources in the atmosphere. This is expected because single particle mass spectrometry suggests that far from sources, organic and inorganic constituents are internally mixed (Murphy et al., 2006), and because under those conditions a thermodynamically stable liquid phase is likely to form (Marcolli et al., 2004). The aerosol in urban areas and near sources, however, is more complex and typically externally mixed (Moffet et al., 2008), further complicating the interaction of reacted BVOC products and pre-existing aerosol.

Finally, reversible and irreversible condensed-phase accretion reactions (Barsanti and Pankow, 2004), may significantly increase condensed-phase products due to esterfication, oligomerization, hemiacetal formation, aldol addition, or Criegee intermediate adduct reactions (Kroll and Seinfeld, 2008), though at least in chamber experiments condensation of biogenic SOA remains reversible upon dilution after many hours (Grieshop et al., 2007). Heterogeneous reactions that proceed at low $\mathrm{pH}$ (a subset of aforementioned reactions) may be particularly important since anthropogenic activities can provide acidic aerosol seed material in the form of sulphuric and nitric acid production from $\mathrm{SO}_{2}$ and $\mathrm{NO}_{\mathrm{x}}$ emissions (Jang et al., 2002).

Zhang et al. (2007b) examined aerosol mass spectrometer (AMS) data collected in Pittsburgh, and found a $25 \%$ increase in SOA mass during periods when the aerosol was more acidic. They did not, however, find evidence for any chemical difference in the SOA which would explain this increase, such as oligomer formation. Takahama et al. (2006) also observed a mild (0.61) correlation between aerosol acidity and OA burden in Pittsburgh, and were also unable to find any evidence for acid catalyzed heterogeneous chemistry which would lead to enhanced SOA. In both cases, the observed increase in OA with aerosol acidity may also be related to processes which affect both acidity and SOA, such as air mass origin and history. On the other hand, several laboratory studies show dramatically increased aerosol yields under acidic conditions (e.g. Edney et al., 2005; Kleindienst et al., 2006; Surratt et al., 2007). Additionally, for SOA formed from isoprene oxidation products, Surratt et al. (2007) demonstrate the existence of particle phase acid catalyzed reactions, leading to the formation of 2-methytetrols, sulphate esters and high molecular weight SOA products. Isoprene derived SOA was also investigated by Edney et al. (2005), who found that concentrations of 2-methyltetrols and 2-methylglyceric acid increased significantly under acidic conditions. In regions where isoprene is present, sulphuric acid seeds may lead to the formation of epoxydiols (Paulot et al., 2009) and reactive uptake of these on acidic aerosols may lead to a 30 -fold increase in OA mass yields from isoprene (Surratt et al., 2010). Similarly, sulphuric acid may pull glyoxal into the particle phase due to esterification (Liggio et al., 2005).

The unreacted forms of the isoprene epoxydiols were detected at relatively low concentrations in ambient aerosol by Chan et al. (2010b). Interestingly, many of the products of the acid catalyzed particle phase reactions of these compounds, such as organosulphates, 2-methyltetrols, 2methylglyceric acid, 2,3-dihydroxymethacrylic acid and $\mathrm{C}_{5}$ alkene triols have also been observed in ambient aerosol (Claeys et al., 2004b; Edney et al., 2005; Surratt et al., 2006), suggesting that these reactions do indeed lead to enhanced aerosol mass in the atmosphere under acidic conditions.

This body of work suggests that (1) equilibrium the equilibrium partitioning framework may not be sufficient to fully model OA aerosol formation unless heterogeneous chemistry is included, and (2) that anthropogenic activities may indeed influence biogenic SOA formation, perhaps explaining the correlation of modern carbon found in the condensed phase with concentrations of anthropogenic OA precursors. 


\subsection{The role of $\mathrm{NO}_{\mathrm{x}}$}

Anthropogenic emissions of $\mathrm{NO}$ compete with $\mathrm{HO}_{2}$ for peroxy radicals formed in the initial stages of VOC oxidation, leading to changes in functional groups and affecting subsequent fragmentation, oligomerization, and isomerisation reactions. Since both carbon chain length and identity of the functional groups affect vapour pressures and solubility in the organic phase, aerosol yields depend on $\mathrm{NO}_{\mathrm{x}}$ concentrations.

While the formation of SOA from biogenic VOCs in the presence of $\mathrm{NO}_{\mathrm{x}}$ has been the subject of many chamber studies, the effect of $\mathrm{NO}_{\mathrm{x}}$ on aerosol yields is complex. The yields depend on many factors including the VOC precursor, the concentration of $\mathrm{NO}_{\mathrm{x}}$, reaction time, and the primary oxidant. A widely used ratio in parameterising yield results, and in yield predictions in models, is the $\mathrm{VOC} / \mathrm{NO}_{\mathrm{x}}$ ratio (ppbC/ppb).

\subsubsection{Nitrate-initiated SOA yields}

SOA mass yields have been reported for the reaction of the nitrate radical $\left(\mathrm{NO}_{3}\right)$, a night-time product of the $\mathrm{NO}_{2}+\mathrm{O}_{3}$ reaction, with isoprene and several monoterpenes (Table 1). Partitioning theory suggests that SOA mass yields should vary with the total SOA mass concentration (Odum et al., 1996; Donahue et al., 2006a), so one must always be careful when comparing experimental datasets. However, direct comparisons for equivalent initial concentrations are certainly valid, and these measurements show a variability well beyond that predicted by partitioning theory alone. This suggests spurious dependences on other experimental conditions and indicates the need for further corroborating studies.

Despite the uncertainties, these large SOA yields from nitrate oxidation present a mechanism for a positive correlation between $\mathrm{NO}_{\mathrm{x}}$ concentrations and SOA formation: regions of high $\mathrm{NO}_{\mathrm{x}}$ and $\mathrm{O}_{3}$ have an additional pathway for SOA formation available via $\mathrm{NO}_{3}$-oxidation of VOCs, which will be most important under high- $\mathrm{NO}_{\mathrm{x}}$ and low-light conditions, where photolabile $\mathrm{NO}_{3}$ has the longest lifetime. In a global modelling study, Hoyle et al. (2007) found that up to $21 \%$ of the global average SOA burden may be due to oxidation of SOA precursors by $\mathrm{NO}_{3}$, during twilight conditions, or early in the night. This percentage increased to around $50-60 \%$ near the surface in industrialised regions, emphasising the importance of anthropogenic emissions for this SOA formation pathway. During a recent measurement campaign in the north-eastern US, between $1 \%$ and $17 \%$ of night-time SOA was found to result from $\mathrm{NO}_{3}$ initiated isoprene oxidation, (Brown et al., 2009). Surratt et al. (2008) find up to $30 \%$ of ambient aerosol at a Hungarian field site to consist of organosulfates, with a significant contribution from nitrooxy organosulphates related to $\mathrm{NO}_{3}$ oxidation of BVOC. In Atlanta, Hennigan et al. (2009) find a peak in gas phase WSOC during the night, which they attribute to $\mathrm{NO}_{3}$ oxidation of
VOC, equalling the daytime peak, although they do not see a corresponding increase in particulate phase WSOC. More field studies, focussing on twilight and night-time chemistry, are needed to quantify the contribution of $\mathrm{NO}_{3}$ initiated $\mathrm{VOC}$ oxidation, especially for biogenic VOC, such as monoterpenes and sesquiterpenes, that are emitted at night from some ecosystems.

\subsubsection{SOA yields in the presence of $\mathrm{NO}_{\mathrm{x}}$}

SOA yields for isoprene and several monoterpenes and sesquiterpenes in the presence of $\mathrm{NO}_{\mathrm{x}}$ have been measured in the laboratory. The yield dependence on $\mathrm{NO}_{\mathrm{x}}$ is complicated when oxidation by ozone or hydroxyl radicals takes place in the presence of $\mathrm{NO}_{\mathrm{x}}$. The primary reason is thought to be that under high $\mathrm{NO}_{\mathrm{x}}$ conditions, organo-peroxy radicals $\left(\mathrm{RO}_{2}\right)$ react with $\mathrm{NO}$ and $\mathrm{NO}_{2}$ instead of with peroxy radicals $\left(\mathrm{RO}_{2}\right.$ or $\left.\mathrm{HO}_{2}\right)$. A number of different critical values (VOC/NO ${ }_{\mathrm{x}}$ ) have been suggested (e.g. 10-15:1, Pandis et al., 1991, 8:1, Presto et al., 2005, 3-10:1, Lane et al., 2008) for the point of 50:50 branching between the two reaction paths. As the $\mathrm{OH} / \mathrm{O}_{3}$ ratio also depends on the $\mathrm{VOC} / \mathrm{NO}_{\mathrm{x}}$ ratio, it is difficult to separate changes in yield due to changes in concentrations of $\mathrm{OH}$ and $\mathrm{O}_{3}$ from changes in product distribution due to the presence of $\mathrm{NO}_{\mathrm{x}}$ (Presto et al., 2005). However, the approach adopted by Lane et al. (2008) is to identify product yields for each fundamental pathway (i.e., high- $\mathrm{NO}_{\mathrm{x}}$ dominated by $\mathrm{RO}_{2}+\mathrm{NO}$, low- $\mathrm{NO}_{\mathrm{x}}$ by $\mathrm{RO}_{2}+\mathrm{HO}_{2}$ ) and then to assume that SOA yields can be calculated by a linear combination of the "pure" mass yields scaled by the strength of each reaction pathway. Clearly, anthropogenic processes that perturb these branching ratios from their background values will influence overall SOA formation.

\section{Isoprene}

The SOA yield of isoprene seems to depend strongly on the conditions used to oxidize isoprene (Carlton et al., 2009). Kroll et al. (2006) indicated that the isoprene SOA yield increases from no injected $\mathrm{NO}_{\mathrm{x}}\left(\mathrm{VOC}: \mathrm{NO}_{\mathrm{x}}\right.$ of more than 225:1) to a plateau between 100 and $300 \mathrm{ppb} \mathrm{NO}_{\mathrm{x}}$ ( $\mathrm{VOC} / \mathrm{NO}_{\mathrm{x}}$ of $2.25: 1$ to $0.75: 1$ ), and decreases at higher $\mathrm{NO}_{\mathrm{x}}$ concentrations. Data from Dommen et al. (2006) show that SOA yields fall on two different plateaus within the investigated $\mathrm{VOC} / \mathrm{NO}_{\mathrm{x}}$ range: low yield for $\mathrm{VOC} / \mathrm{NO}_{\mathrm{x}}$ ratios from 25:1 to 10.5:1 and high yield for 10.5:1 to 7:1. Chan et al. (2010a) show that SOA yields increase for VOC: $\mathrm{NO}_{\mathrm{x}}$ values between 0.1:1 to $1: 1$ and then decrease. Together these three sets of experiments (Fig. 1) show an optimal range of VOC: $\mathrm{NO}_{\mathrm{x}}$ values between 10:1 and 1:1 for SOA yield from isoprene. However, it is important to note the differing oxidant conditions $\left(\mathrm{HO}_{2}\right.$ generated from $\mathrm{RO}+\mathrm{O}_{2}$ in Dommen et al., 2006; from $\mathrm{OH}+\mathrm{H}_{2} \mathrm{O}_{2}$ in Kroll et al., 2006) present in these two experiments, which may skew the $\mathrm{RO}_{2}$ radical fate. 
Table 1. SOA yields for $\mathrm{NO}_{3}$-initiated experiments.

\begin{tabular}{|c|c|c|}
\hline VOC & Yield & Notes \\
\hline $18-120 \mathrm{ppb}$ isoprene & $4-24 \% 1$ & $\begin{array}{l}\text { Higher yields observed when oxidant } \\
\text { was introduced slowly }\end{array}$ \\
\hline $11 \mathrm{ppb}$ isoprene & $2 \%^{2}$ & $\begin{array}{l}\text { Second generation products contribute to the } \\
\text { yield more than first generation products }\end{array}$ \\
\hline $50-500 \mathrm{ppb} \alpha$-pinene & $4-16 \%{ }^{3}$ & $\begin{array}{l}\text { Higher yields at lower } \mathrm{RH} \text { and the } \\
\text { use of organic seed aerosol }\end{array}$ \\
\hline $18-580 \mathrm{ppb} \alpha-$ pinene & $0-16 \%^{2}$ & - \\
\hline 7-358 ppb $\beta$-pinene & $10-52 \%^{2}$ & $\begin{array}{l}\text { Found largest yields at } \\
\text { intermediate concentrations }\end{array}$ \\
\hline $15 \mathrm{ppb} \beta$-pinene & $50 \%{ }^{5}$ & $\begin{array}{l}\text { No yield dependence on relative } \\
\text { humidity }(0-60 \%)\end{array}$ \\
\hline $18 \mathrm{ppb}$ limonene & $17 \%{ }^{4}$ & - \\
\hline $500 \mathrm{ppb}$ limonene & $21-40 \%^{3}$ & $\begin{array}{l}\text { Higher yields found with organic } \\
\text { vs. }\left(\mathrm{NH}_{4}\right)_{2} \mathrm{SO}_{4} \text { seed }\end{array}$ \\
\hline $7-395 \mathrm{ppb} \Delta^{3}$-carene & $15-62 \% 4$ & - \\
\hline
\end{tabular}

${ }^{1} \mathrm{Ng}$ et al., 2008, ${ }^{2}$ Rollins et al., 2009, ${ }^{3}$ Spittler et al., 2006, ${ }^{4}$ Hallquist et al., 1999, ${ }^{5}$ Fry et al., 2009.

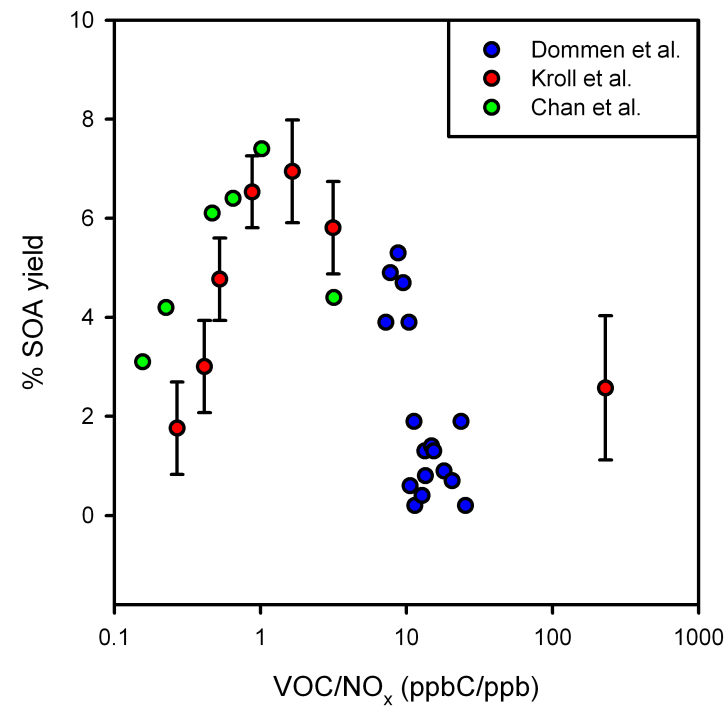

Fig. 1. Percentage yield of SOA vs $\mathrm{VOC} / \mathrm{NO}_{\mathrm{x}}$ ratio, for experiments performed by Dommen et al. (2006), Kroll et al. (2006), and Chan et al. (2010a). The highest yields are observed at $\mathrm{VOC} / \mathrm{NO}_{\mathrm{x}}$ ratios between 1 and 10. All data are normalized to density $=1.4 \mathrm{~g} \mathrm{~cm}^{-3}$. Because the $\mathrm{NO}_{\mathrm{x}}$ concentration for the data point at the highest $\mathrm{VOC} / \mathrm{NO}_{\mathrm{x}}$ ratio is $<1 \mathrm{ppb}$, this data point represents the lower bound for the $\mathrm{VOC} / \mathrm{NO}_{\mathrm{x}}$ ratios.

Yields for low VOC: $\mathrm{NO}_{\mathrm{x}}$ ratios reported by Chan et al. (2010a) are higher than those reported by Kroll et al. (2006). The experiments of Chan et al. (2010a) were carried out at atmospherically relevant $\mathrm{NO}_{2} / \mathrm{NO}$ ratios (3-
8), which favors the formation of a second generation product methacryloylperoxynitrate (MPAN), which in turn leads to aerosol formation upon further oxidation (Surratt et al., 2010). $\mathrm{NO}_{2}$ was also found to increase the SOA formation from acrolein and crotonaldehyde (Chan et al., 2010a), and therefore similar effects may be seen for other VOC which have $\alpha, \beta$-unsaturated aldehydes as oxidation products. The low VOC: $\mathrm{NO}_{\mathrm{x}}$ SOA yields measured by Chan et al. (2010a) were also larger than those seen by Kroll et al. (2006) for high VOC: $\mathrm{NO}_{\mathrm{x}}$ ratios. Since the $\mathrm{NO}_{2} / \mathrm{NO}$ ratio tends to be higher in urban regions than rural regions, this suggests that SOA from isoprene and particular other VOC could actually be enhanced in urban areas. This is certainly an effect which warrants further investigation, particularly though field studies.

Further, as discussed in Sect. 2.1, aerosol acidity has been observed to increase isoprene SOA formation (e.g. Edney et al., 2005; Surratt et al., 2007) probably through reactive uptake of epoxydiols formed from isoprene at low- $\mathrm{NO}_{\mathrm{x}}$ conditions (Surratt et al., 2010; Paulot et al., 2010).

\section{Monoterpenes and oxymonoterpenes}

The formation of SOA in the presence of $\mathrm{NO}_{\mathrm{x}}$ has been studied for several monoterpenes: $\alpha$-pinene, $\beta$-pinene, limonene, 3 -carene, myrcene, $\beta$-ocimene, sabinene, $\alpha$-terpinene, $\alpha$ terpinolene (Pandis et al., 1991; Hoffmann et al., 1997; Griffin et al., 1999; Klinedinst and Currie, 1999b; Presto et al., 2005; Lee et al., 2006; Zhang et al., 2006). The complexity of the dependence of $\mathrm{NO}_{\mathrm{x}}$ concentration on monoterpene SOA yields was first noted by Pandis et al. (1991) who found 
that the SOA yield from the photooxidation of $\beta$-pinene increased with increasing $\mathrm{VOC} / \mathrm{NO}_{\mathrm{x}}$ ratio and maximized at $8 \%$ for $10-20 \mathrm{ppbC}: \mathrm{ppb} \mathrm{NO}_{\mathrm{x}}$. The SOA yield was found to decrease for $\mathrm{VOC} / \mathrm{NO}_{\mathrm{x}}$ ratios greater than 20 .

More recently, Presto et al. (2005) showed that SOA yields from ozonolysis of $\alpha$-pinene are lower under high$\mathrm{NO}_{\mathrm{x}}\left(<15\right.$ ppbC:ppb $\left.\mathrm{NO}_{\mathrm{x}}\right)$ than low- $\mathrm{NO}_{\mathrm{x}}$ conditions. The reduction of the SOA yields was attributed to the formation of higher volatility products under high $\mathrm{NO}_{\mathrm{x}}$, including evidence of nitrate-containing organic species.

The $\mathrm{NO}_{\mathrm{x}}$ dependence becomes increasingly complex when the monoterpene consists of two double bonds with differing reactivity, as is the case for limonene. Zhang et al. (2006) indicated that two competing effects contribute to the $\mathrm{NO}_{\mathrm{x}}$ dependence of the SOA yield: reactive uptake by the aerosol and gas-phase oxidation. In the presence of ozone and at low $\mathrm{NO}_{\mathrm{x}}$, heterogeneous ozonolysis of the exo double bond generates condensed-phase secondary generation oxidation products. However, at high $\mathrm{NO}_{\mathrm{x}}$, gas-phase oxidation of the double bond becomes the dominant process for aerosol product generation.

The SOA mass yields have been measured for a few oxygenated biogenic compounds (Table 2). Again, since aerosol partitioning depends on the total concentration of organic matter, direct comparisons of mass yields are difficult. Nevertheless, this shows the high variability among monoterpenoid species and generally higher yields from sesquiterpenes.

\section{Sesquiterpenes}

Oxidation of the highly reactive sesquiterpenes in the presence of $\mathrm{NO}_{\mathrm{x}}$ can also create significant SOA mass concentrations (Table 2). In the case of sesquiterpenes, higher $\mathrm{NO}_{\mathrm{x}}$ concentrations are correlated with higher SOA yields, the opposite dependence from that observed in monoterpenes. This is presumably due to the lower volatility of the sesquiterpene nitrates.

Clearly, the ratio of $\mathrm{NO}_{\mathrm{x}}$ concentration to biogenic VOC concentration has a pronounced effect on the SOA yield, providing a further mechanism through which anthropogenic emissions modify the SOA production in the atmosphere. However, this dependence is complex and shows everything from a strong positive correlation between $\mathrm{NO}_{\mathrm{x}}$ concentration and SOA to a strong negative correlation over the range of biogenic VOCs studied to date. This suggests the need for explicit treatment of sub-classes of biogenic VOC in models, including $\mathrm{NO}_{\mathrm{x}}$ dependence, rather than applying lumped BVOC SOA yields.

\subsection{Potential for modification of BSOA in pristine envi- ronments}

There is significant potential for anthropogenic effects on BSOA in relatively pristine environments.
The high insolation and abundant vegetation in Amazonia make this region a global hotspot for the emission of various biogenic volatile organic compounds (e.g. Rasmussen and Khalil, 1988; Keller et al., 2009). Previously it was thought that the vast emissions of VOC in the Amazon area would deplete the oxidative potential of the atmosphere (Lelieveld et al., 2002) and thus constrain the BSOA production. However, there have been strong indications that $\mathrm{HO}_{\mathrm{x}}$ chemistry remains substantially more vigorous under low- $\mathrm{NO}_{\mathrm{x}}$, high-isoprene conditions than standard mechanisms predict (Thornton et al., 2002). This was confirmed by a more recent study by Lelieveld et al. (2008) showing that the oxidative potential in the pristine rainforest is maintained through the recycling of $\mathrm{OH}$ via organic peroxy radical reactions under low $\mathrm{NO}_{\mathrm{x}}$ conditions. Most attempts to estimate Amazonian BSOA production (e.g. Penner et al., 2001; Kanakidou et al., 2005) with global models have considered only monoterpenes as precursors. More recent efforts (e.g. Heald et al., 2008) have included isoprene, which has been shown to be a significant SOA precursor (Claeys et al., 2004a), but still omit some potentially significant precursors such as the highly reactive sesquiterpenes which have very high BSOA yields. Both observational and modelling studies have concluded that ca. $80 \%$ of the aerosol mass in the Amazon forest is of biogenic origin (Artaxo et al., 1990; Artaxo and Hansson, 1995; Heald et al., 2008; Q. Chen et al., 2009) either due to primary or secondary sources (Kanakidou et al., 2005), however there is a large uncertainty in this number. One has to keep in mind that unless we have an accurate knowledge of the emissions of primary aerosols, it will be difficult to assess the relative importance of the SOA. Measurements made during the Amazonian Aerosol Characterization Experiment 2008 (AMAZE-08), under near pristine conditions, show that the submicrometer aerosol is mostly composed of BSOA, while supermicron particles consist mainly of primary organic matter (Pöschl et al., 2010). While the submicrometer fraction was found to account for more than $99 \%$ of the ca. $200 \mathrm{~cm}^{-3}$ particles observed, approximately $70 \%$ of the ca. $2 \mu \mathrm{g} \mathrm{m}^{-3}$ total particle mass was made up by the supermicron particles.

The ongoing development of the Amazon is resulting in an enhanced anthropogenic influence on regional atmospheric composition. Changes in anthropogenic pollutants (particularly $\mathrm{NO}_{\mathrm{x}}$ and $\mathrm{SO}_{2}$ ) can alter the $\mathrm{SOA}$ formation potential (Kroll et al., 2005; $\mathrm{Ng}$ et al., 2007) and the relative roles of different oxidation pathways. It is typically assumed that more $\mathrm{SOA}$ is formed from monoterpenes under low- $\mathrm{NO}_{\mathrm{x}}$ conditions, such as prevail in the Amazon. However, for some compounds and conditions, the opposite is true (see Sect. 2.2). Therefore a change in the amount of $\mathrm{NO}_{\mathrm{x}}$ due to anthropogenic emissions would lead to a change in the amount of SOA. The magnitude and the sign of this change depend on the predominant VOC species. The available mass of existing OA also plays a role, as described in Sect. 2.1. Because of the dependence of Amazonian emissions of BVOC 
Table 2. SOA yields from VOCs in the presence of $\mathrm{NO}_{\mathrm{x}}$.

\begin{tabular}{|c|c|c|c|}
\hline VOC & Mass Yield & Oxidant & $\begin{array}{l}\mathrm{VOC} \mathrm{NO}_{\mathrm{x}} \text { ratio } \\
\left(\mathrm{ppb} \mathrm{C} / \mathrm{ppb} \mathrm{NO}_{\mathrm{X}}\right)\end{array}$ \\
\hline \multicolumn{4}{|l|}{ Oxygenated compounds } \\
\hline 72 ppb linalool ${ }^{1}$ & $6 \%$ & Photo-oxidation & 4 \\
\hline $80-230$ ppb linalool $^{2}$ & $3-5 \%$ & Photo-oxidation & $8-11$ \\
\hline 124 ppb linalool $^{3}$ & $13 \%$ & Photo-oxidation & 10 \\
\hline 78 ppb linalool $^{2}$ & $8 \%$ & Ozone & No $\mathrm{NO}_{\mathrm{x}}$ \\
\hline $116 \mathrm{ppb}$ terpinen-4-ol ${ }^{1}$ & $6 \%$ & Photo-oxidation & 4 \\
\hline $70-230 \mathrm{ppb}$ terpinen-4-ol ${ }^{2}$ & $3-6 \%$ & Photo-oxidation & $8-11$ \\
\hline $90 \mathrm{ppb}$ terpinen-4-ol ${ }^{2}$ & $34 \%$ & Ozone & No $\mathrm{NO}_{\mathrm{x}}$ \\
\hline 105 ppb verbenone ${ }^{3}$ & $19 \%$ & Photo-oxidation & 11 \\
\hline 79 ppb methyl chavicol ${ }^{3}$ & $40 \%$ & Photo-oxidation & 8 \\
\hline \multicolumn{4}{|l|}{ Sesquiterpenes } \\
\hline 5-9 ppb $\alpha$-humulene ${ }^{1}$ & $32-73 \%$ & Photo-oxidation & $1-3$ \\
\hline $46 \mathrm{ppb} \alpha$-humulene ${ }^{3}$ & $65 \%$ & Photo-oxidation & 9 \\
\hline $6-13 \mathrm{ppb} \beta$-caryophyllene ${ }^{1}$ & $37-79 \%$ & Photo-oxidation & $3-8$ \\
\hline $100 \mathrm{ppb} \beta$-caryophyllene ${ }^{2}$ & $100-125 \%$ & Photo-oxidation & 9 \\
\hline $37 \mathrm{ppb}$ ppb $\beta$-caryophyllene ${ }^{3}$ & $68 \%$ & Photo-oxidation & 19 \\
\hline $118 \mathrm{ppb} \gamma$-caryophyllene ${ }^{3}$ & $29 \%$ & Photo-oxidation & 11 \\
\hline $34 \mathrm{ppb}$ longifolene ${ }^{4}$ & $65 \%$ & Photo-oxidation & 19 \\
\hline $34 \mathrm{ppb}$ aromadrene $\mathrm{e}^{4}$ & $37 \%$ & Photo-oxidation & 21 \\
\hline
\end{tabular}

${ }^{1}$ Griffin et al., 1999; ${ }^{2}$ Hoffmann et al., 1997; ${ }^{3}$ Lee et al., 2006; ${ }^{4}$ Ng et al., $2007 b$.

and $\mathrm{NO}_{\mathrm{x}}$ on factors like season, rain, forest or biomass fires, it will be challenging to estimate the possible anthropogenic effects using large scale models.

It is, however, the number of SOA particles that exceed a certain size threshold determined by their chemical composition (or hygroscopicity), that determines the number of cloud droplets that are formed (Roberts et al., 2002). The latter is the necessary quantity to assess indirect effects of aerosols on clouds and precipitation (Lohmann and Feichter, 2005). One of the potentially largest anthropogenic influences on the SOA in pristine environments would be an increase in the number of aerosol particles through a modification of new particle formation.

\subsection{New particle formation and growth}

A modelling study by Merikanto et al. (2009) showed that on a global average, about half of all Cloud Condensation $\mathrm{Nu}$ clei (CCN) originated from SOA. Yu and Luo (2009) claimed that secondary particles even dominate the number abundance in most parts of the troposphere $(>80 \%)$. However, other studies suggest that the effect of new-particle formation on CCN numbers, even with artificially enhanced SOA formation, remains modest (Pierce et al., 2008). Both the initial formation of the new particles and their subsequent growth to $\mathrm{CCN}$ size play a crucial role in the global climate.
New particle formation events have been observed to occur in both the cleanest environments (e.g. Antarctica, Koponen et al., 2003) and the most polluted regions, (e.g. India and China Möonkkönen et al., 2005; Wehner et al., 2005) of our planet, as reviewed in Kulmala et al. (2004) and Kulmala and Kerminen (2008). At coastal locations, biogenic iodine has been identified as a key component (Hoffmann et al., 2001; O'Dowd et al., 2002) influencing particle formation. In continental locations, sulphuric acid has been proposed as a plausible candidate for the initial particle formation (Weber et al., 1996; Kulmala et al., 2004; Kuang et al., 2008; Nieminen et al., 2009). On the other hand, chamber experiments (e.g. VanReken et al., 2006; Burkholder et al., 2007) and theoretical studies (Bonn et al., 2008, 2009; Boy et al., 2008) raise the possibility that organic vapours may be the key molecules for the nucleation mechanism.

Boy et al. (2003, 2008) showed that for the boreal forest in Central Finland and for an elevated forest in the Front Range of the Colorado Rocky Mountains, USA, sulphuric acid can only explain a small fraction (10-30\%) of the observed particle growth. In boreal forest Kulmala et al. (2001) attributed the rest of the growth to condensable organics, which is in line with the aerosol mass spectrometer results by Allan et al. (2006) and indirect results by Tunved et al. (2006). There is, however, large variability in the relative roles of the organics and anthropogenic sulphuric acid. 
In more anthropogenically influenced areas, such as Atlanta, USA, the contribution of sulphuric acid was found to be up to $100 \%$ (Stolzenburg et al., 2005), depending on local conditions and air mass origin. In Pittsburgh, USA, ultrafine mode particles (18-33 nm diameter) were examined by (Zhang et al., 2004), who found that during nucleation events, sulphate was always the first aerosol component to increase, followed by ammonium, with organics contributing to the later growth.

The details of the participating compounds and their relative roles are still uncertain, but the oxidized organics are definitely involved in the growth of the freshly formed aerosol particles to climatically active sizes (Kulmala et al., 2001; Stolzenburg et al., 2005; Wehner et al., 2005; Smith et al., 2008). Thus, oxidized organics strongly contribute to the global indirect effect via cloud droplet activation.

The precursors for sulphuric acid are both anthropogenic (i.e. $\mathrm{SO}_{2}$ ) and biogenic (i.e. DMS). Also the VOCs have sources in both categories, which oxidize in the atmosphere to form condensable organic vapours. Assuming that sulphuric acid (Sipila et al., 2010) and consequently sulphur dioxide is the limiting factor in new particle formation, the predicted global average decrease of $\mathrm{SO}_{2}$ emissions by more than half assumed for the global model simulation in the next IPCC report would cause a dramatic decrease in SOA number concentrations, with an associated reduction in the negative radiative forcing via the indirect aerosol effect. By contrast, if regional $\mathrm{SO}_{2}$ emissions would increase - particularly in countries with fast growing populations and less financial and technological emission reduction possibilities relatively unpolluted regions such as the Amazon could be subjected to higher sulphuric acid concentrations, which may lead to regionally elevated particle formation rates.

Rizzo et al. (2010), found no evidence for new-particle formation in a relatively pristine area of the Amazon, and suggested that this could be due to the low levels of $\mathrm{SO}_{2}$ in this region. There are also other possible explanations for these observations, for example that particle formation took place in the boundary layer or free troposphere and that the particles which reached the instruments in the canopy had grown since nucleation. Additionally, in this environment the high VOC emissions (Rasmussen and Khalil, 1988; Keller et al., 2009) in connection with sustained atmospheric oxidant capacity (Lelieveld et al., 2008) could lead to a high production rate of condensable vapors, thus causing the particles to rapidly grow out of the nucleation mode sizes via multicomponent condensation.

Any enhanced particle formation due to higher $\mathrm{SO}_{2}$ levels may be greater in summer and in tropical regions where the oxidation of $\mathrm{SO}_{2}$ via peroxides is more rapid (Goldstein et al., 2009) and where furthermore the VOC emissions, and subsequently the concentrations of condensable organic compounds are higher. A further complication arises from the interconnections of anthropogenic and biogenic emissions and compounds. The organic precursors also influence the oxidative potential of the atmosphere (Kiendler-Scharr et al., 2009) by acting as $\mathrm{OH}$ scavengers, and thus affect the oxidation of both anthropogenic and biogenic precursors, potentially inhibiting new particle formation.

Very recent computational studies with quantumchemistry and first experiments in chambers and flow tubes resulted in strong evidence that amines could be important and explain the missing puzzle-piece in the particle formation process. Loukonen et al. (2010) studied the hydration of sulfuric acid- dimethylamine clusters and found dimethylamine enhances the addition of sulfuric acid to the clusters much more efficiently than ammonia when the number of water molecules in the cluster is either zero, or greater than two. More research is needed, however amines may play a major role in the nucleation process.

To quantify the net effects of mutually intermingled SOA and anthropogenic precursors in atmospheric nucleation, and to predict their impacts on $\mathrm{CN}$ and $\mathrm{CCN}$ concentrations in the future climate requires a complete picture of the specific molecules taking part in the initial nucleation, including a knowledge of differences in new particle formation pathways between pristine and polluted environments. Such detailed information does not currently exist.

\section{Methods for separating the contributions of different sources to organic aerosol}

A sample of ambient organic aerosol will generally contain a fairly reduced POA fraction and a more oxidised SOA fraction. Zhang et al. (2005a) developed a method to use mass spectra to determine the mass concentrations of hydrocarbon-like organic aerosol (HOA) and oxygenated organic aerosol (OOA) in a sample. It has been shown that OOA corresponds with SOA (e.g. de Gouw et al., 2005; Zhang et al., 2005b). HOA is almost without exception less abundant than OOA, even in urban settings, and it appears to be relatively stable downwind of source regions (Zhang et al., 2007a; DeCarlo et al., 2010). A complication is biomass burning OA (BBOA), which can be relatively oxidized and water soluble (Graham et al., 2002; Mayol-Bracero et al., 2002; Baduel et al., 2010). However, Sullivan et al. (2004) suggested a substantial fraction of the water soluble organic carbon (WSOC) measured at an urban site during the day time in June may be related to SOA. In the work of Weber et al. (2007) WSOC was used as a measure of SOA. It was shown by Kondo et al. (2007) that OOA correlates strongly with the WSOC fraction of samples from Tokyo, supporting the idea that WSOC is related to SOA.

The vast majority of observed SOA can be linked to emissions from the following three source classes:

Fossil fuel combustion (FSOA) - emissions due to the use of fossil fuels. This category also includes emissions due to evaporation during fossil fuel extraction, processing and transportation. This source category is 
unequivocally anthropogenic, and it is what determinations of fossil carbon content seek to constrain.

Biomass and biofuel burning (BBOA and BBSOA) partly anthropogenic and partly natural, emissions in this category are from forest fires, agricultural waste burning, domestic cooking and heating fires, meat cooking etc. Anthropogenic influence can be either direct (i.e., cooking or agricultural fires) or indirect (i.e., land use changes and/or forest management practices).

BVOCs - (BSOA) the non-combustion related emission of VOCs from plants. Here there are also anthropogenic modifications due to land use and atmospheric change that are associated with large impacts on regional scales and significant global effects. We can in turn split the BVOC fraction into two sub fractions: natural BSOA and anthropogenically enhanced BSOA (eBSOA). eBSOA represents the SOA fraction from naturally emitted BVOC which may result from an interaction with anthropogenic emissions, as discussed above and in more detail below.

A major objective of this paper is to describe a methodology for separating OA into the fractions identified above. Furthermore, the essential challenge can be summarised as follows. OA levels are almost without fail higher in urban areas than in remote areas. This includes extremely high levels in megacities such as Mexico City (Salcedo et al., 2006; DeCarlo et al., 2008; Aiken et al., 2009; Hodzic et al., 2009) and Beijing (Sun et al., 2010). However, even in these settings OOA is the major OA fraction (Zhang et al., 2007a; Jimenez et al., 2009). While source attribution and modelling studies point to a very large anthropogenic SOA source from mobile sources (i.e. transportation using fossil fuels), (e.g. Schauer et al., 2002; Docherty et al., 2008; Yin et al., 2010), ${ }^{14} \mathrm{C}$ measurements suggest a substantial modern fraction. Understanding this is a great challenge.

We propose the following general methodology (summarised in Fig. 2), in line with the recent work of Szidat et al. (2006, 2009): beginning with an aerosol sample containing a certain fraction from each of the above categories, a separation of the sources may be made as follows: the apportionment of the fossil fuel combustion fraction of organic aerosol can be made via ${ }^{14} \mathrm{C}$ analysis, as ${ }^{14} \mathrm{C}$ is depleted in compounds of fossil origin due to radioactive decay. In such calculations it is important to take into account that wood grown during the last 6 decades has elevated ${ }^{14} \mathrm{C}$ levels, due to atmospheric nuclear bomb tests. $\mathrm{A}{ }^{14} \mathrm{C}$ isotopic ratio of $1.16 \pm 0.05$ is used for OA from wood combustion, by Szidat et al. (2009).

The remaining fraction then contains OA from BVOCs and combustion of modern biogenic matter. Combustion processes result in the formation of elemental carbon (black carbon, or soot) aerosols ("EC", "BC" or soot), and a correlation between a time series of these and that of OA can be used to

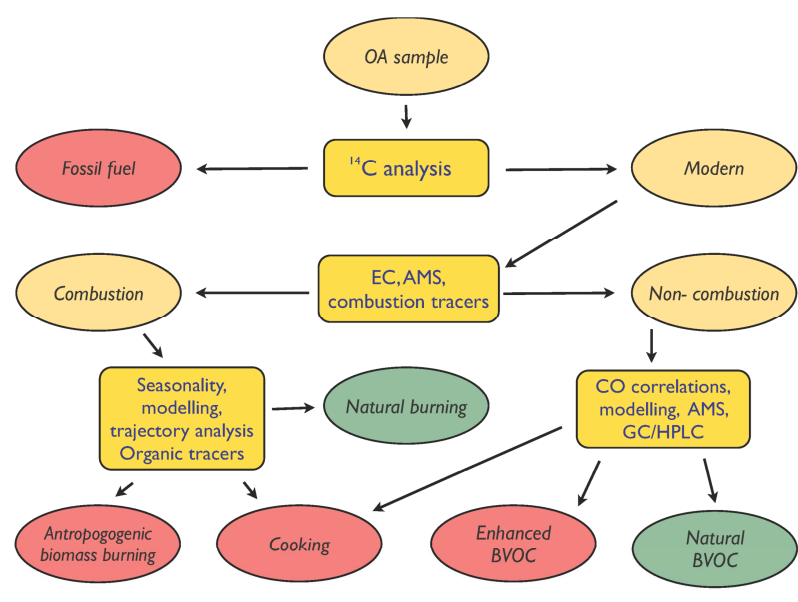

Fig. 2. A schematic depiction of the methods for source apportionment of the various fractions of observed organic aerosol. Enhanced SOA (eBSOA) results from an anthropogenic enhancement of SOA from BVOC, therfore we differentiate between natural BVOC and enhanced BVOC, even though the species and emission mechanisms are identical, as described in Sect. 3. The rectangles describe some of the techniques and marker compounds used to seperate the different fractions. $\mathrm{EC}=$ elemental carbon, $\mathrm{AMS}=$ aerosol mass spectrometer, GC = gas chromatography, HPLC = high-pressure liquid chromatography.

determine the fraction of $\mathrm{OA}$ which results from combustion (e.g. Gustafsson et al., 2009; Szidat et al., 2009). This requires knowledge of the average emission ratios for OC and EC from the various burning processes that need to be taken into account (e.g. domestic wood fires, Szidat et al., 2006). To extract the contemporary fraction of the combustion related OA, only the modern fraction of the EC aerosol must be considered. Similarly, levoglucosan can be used instead of EC to determine the combustion related fraction of modern OA (e.g. Sullivan et al., 2008; Szidat et al., 2009).

A recent Aerosol mass spectrometer (AMS) study by Lee et al. (2010) shows that in very fresh smoke (with an age of around $30 \mathrm{~s}$ ), both for flaming and smoldering combustion conditions, molecular fragments with a mass-to-charge ratio $(\mathrm{m} / \mathrm{z})$ of 60.021 correlate very well with measurements of $\mathrm{OA}$. The experiments were performed with several different fuels, suggesting that AMS measurements may be valuable in estimating the contribution of POA from biomass burning to ambient $\mathrm{OA}$.

The remaining fraction of the sample which is not from combustion processes contains mostly OA formed from natural emissions of BVOC, however it may still be comprised of a natural fraction and an anthropogenically enhanced fraction. It may also contain substantial quantities of OA derived from cooking. Qualitatively, these fractions may be separated by the comparison of measurements from an urban and nearby rural site (e.g. Szidat et al., 2009).

A quantitative separation may be achieved via measurements within the urban area, as well as up- and downstream 
of it. A tracer of anthropogenic emissions (CO levels which are elevated over the background values, for example) may be used to estimate the dilution of the urban plume (e.g. de Gouw et al., 2005; Weber et al., 2007). De Gouw et al. (2005) suggests that the removal of anthropogenic VOCs and production of ASOA in an air mass, as it travels from an urban source region, can be estimated by using three parameters, namely a relatively inert pollution tracer (e.g. acetylene or $\mathrm{CO}$ ), hydrocarbon ratios, and the chemical kinetics of the reactions occurring in the air mass. If the production of ASOA, as the plume ages downstream of the urban area, is known, as well as BVOC and BSOA concentrations upstream of the urban area, an anthropogenic enhancement of BSOA can be calculated. The kinetics of BSOA formation from BVOC in chemically unperturbed conditions must also be known, and there are considerable uncertainties associated with the modelling of SOA production.

A further way to separate the two fractions is to use a model where a simulation with and without anthropogenic emissions can be performed. Of course, such a simulation must accurately represent the chemistry and thermodynamics of both biogenic and anthropogenic OA, as well as their interactions.

The sample fraction related to emissions via the combustion of modern biogenic material, for example from natural and non-natural forest fires, agricultural waste burning, cooking and heating can also be further broken down into a natural and an anthropogenic fraction. Almost all combustion of modern biogenic material in urban areas is anthropogenic, therefore an urban plume tracer correlation analysis can be carried out, and all modern combustion related OA coming from the urban area can be categorised as anthropogenic, if no natural biomass burning events took place upwind of the urban area.

On the other hand, emissions of molecular markers as a function of $\mathrm{OC}$ emissions, (for example levoglucosan/OC or n-alkane/OC ratios) have been measured for different biomass types and for different burning situations such as residential, wild fire or agricultural burning (e.g. Fine et al., 2001, 2002; Hays et al., 2005; Iinuma et al., 2007; Mazzoleni et al., 2007, Sullivan et al., 2008). Shrivastava et al. (2007) suggest that large even-numbered alkanoic acids (hexacosanoic, octacosanoic, triacontanoic and dotriacontanoic acids) can be used to identify open burning as well as non-combustion emissions of low volatility organic compounds, where the use of levoglucosan as a tracer can separate the combustion and non-combustion fractions. There are some significant uncertainties in these methods, as the ratio of the molecular marker to $\mathrm{OC}$ is rather variable, even for the same combustion material and situation, and the ambient concentrations of the markers is highly variable due to the multitude of different sources with different emission profiles (e.g. Fine et al., 2001; Robinson et al., 2006; Mazzoleni et al., 2007).
Nevertheless, the use of such molecular markers makes it possible to estimate the fraction of the combustion-related modern OA that comes from different burning situations, allowing an approximate separation of clearly anthropogenic sources such as domestic wood burning for heating or cooking and agricultural waste burning.

One factor which needs to be addressed is the effect of atmospheric ageing on biomass burning markers, and their ratio to OA. This is currently not well quantified, however recent experimental work strongly suggests that both levoglucosan (Hennigan et al., 2010) and the $m / z=60$ biomass burning marker (Grieshop et al., 2009) decay significantly during photochemical oxidation in chambers.

Obviously, in the case of forest fires, it is not generally possible to differentiate between natural and anthropogenic events based on molecular markers. Trajectory modelling from known fires, combined with an emissions estimate may be the only useful method in this case. The seasonality of burning events can also be used in longer time series to apportion observed OA to its source - emissions from fires for domestic heating peak in winter, and agricultural waste burning and other open fires also have a seasonal dependence.

The only suitable method that would quantatitively account for the anthropogenic enhancement of OA from natural fires would be a modelling study, where anthropogenic emissions were turned on and off.

Emissions from cooking have been found to contribute to 5-24\% of OA at urban locations (Rogge et al., 1991; Zheng et al., 2002; Huang et al., 2010; Sun et al., 2010), and the influence of POA from cooking may now be comparable to POA from motor vehicle emissions (Allan et al., 2010; Sun et al., 2010). The OA contribution from cooking emissions should thus preferably be constrained in source apportionment studies by measurements of molecular marker compounds using off-line techniques (see e.g. Rogge et al., 1991; Zheng et al., 2002) or on-line gas chromatography (e.g. Williams et al., 2006), or by measurements of relevant mass fragments using an aerosol mass spectrometer (Sun et al., 2010; Allan et al., 2010; Huang et al., 2010).

In the possibilities for source apportionment described above, emissions of modern, non-volatile organic compounds through non-combustion related anthropogenic activities have not been accounted for. This includes emissions such as the natural rubber content of tire dust, and paved road dust (Fine et al., 2001). However, these are comparatively small sources, and in relation to the other substantial uncertainties in the source separation they are unlikely to lead to significant errors.

Compounds such as organosulfates and nitrooxyorganosulfates from oxidation of isoprene and monoterpenes may serve as potential tracers of anthropogenic enhancement of BSOA since these molecules are formed in reactions involving BVOC and sulphate (e.g. Iinuma et al., 2007; Surratt et al., 2008; Nozière et al., 2010). Sulphate sources in the specific study region should obviously be evaluated, 
to account for the relative contribution of anthropogenic and natural sources (DMS and volcanoes). Unfortunately, quantitative studies would presently be hampered by the lack of commercially available authentic standards for organosulfates.

On long time scales, the distribution of different vegetation types, their emissions of BVOCs and therefore the formation of BSOA, will be influenced by atmospheric changes such as increasing temperatures, shifting rainfall patterns, changes in ozone and carbon dioxide concentrations. These changes can undoubtedly be classified as an anthropogenic modification. The net effects of the combination of such factors on SOA burdens is highly uncertain. Due to the long timescales involved, the resulting changes in SOA may be best quantified by modelling both the vegetation and atmospheric systems, for example Heald et al. (2008), J. Chen et al. (2009).

Given the possibilities for source apportionment, we next consider whether there is any evidence from observational work for a substantial enhancement of natural SOA via interaction with anthropogenic emissions.

\section{Observational and modelling data}

\subsection{Observations from remote, rural and urban areas}

An overview of several investigations of atmospheric compounds and components is presented in Fig. 3. Measurements of total VOCs in urban areas show low contemporary carbon percentages $(0-40 \%)$, probably reflecting the contribution of long-lived VOCs from the combustion of fossil fuels. In these studies, a larger contribution of contemporary carbon to atmospheric oxidation products, such as carbonyl compounds, formic and acetic acids, was found during summer than during winter. Both carbonyl compounds and formic and acetic acids have relatively high percentages of contemporary carbon (carbonyls $39-84 \%$, formic and acetic acids 55-100\%) even in urban environments. As the main urban source of modern VOC stems from the use of biofuels such as wood, for heating, this greater abundance of contemporary carbon in the oxidation products in summer points to a very large influence of BVOC emissions from natural sources. Indeed, the separation of the $\mathrm{OC}$ values into wood-burning OC and biological OC in the work of Szidat et al. (2009), show that the higher levels of modern OC observed in Goteborg in summer than winter are natural in origin.

A number of studies have investigated the relative contribution of fossil and contemporary carbon in particulate matter (PM) and a few are included in Fig. 3. The range of contemporary carbon contribution is broader for the fine PM than for individual compounds or compound groups in Fig. 3, reflecting the diversity in chemical composition and sources of carbon in PM. Observed fractions of contemporary carbon in fine PM range from 0.46 to 0.95 in summer (Szidat et al.,

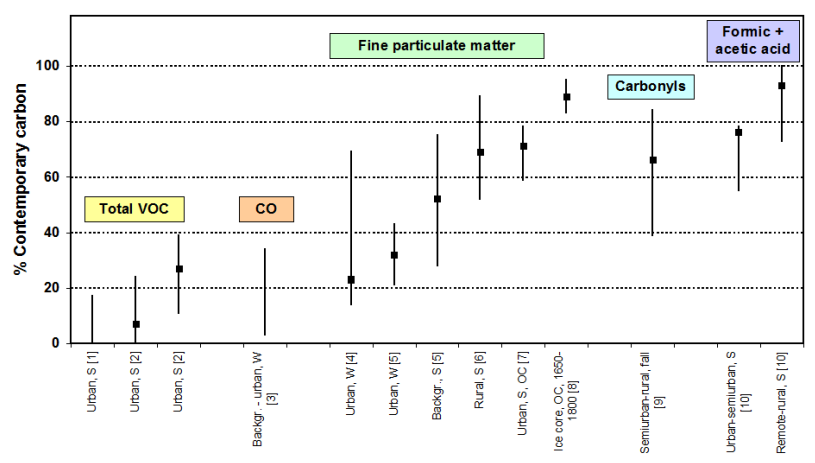

Fig. 3. Relative amount of contemporary carbon in measurements made in different situations and seasons. Ranges are shown together with the median value. Summer is indicated by " $S$ " and winter by "W". The plot is an update of the one shown in Larsen et al. (2001). "Total VOC" are volatile organic compounds excluding methane. [1] (Klouda et al., 1996) [2] (Klouda et al., 2002) [3] (Klouda and Connolly, 1995) [4] (Klinedinst and Currie, 1999a) [5] (Glasius et al., 2011) [6] (Lewis and Stiles, 2006) [7] (Szidat et al., 2009) [8] (Jenk et al., 2006) [9] (Larsen et al., 2001) [10] (Glasius et al., 2001).

2004; Lewis and Stiles, 2006; Bench et al., 2007; Gelencsér et al., 2007; Takahashi et al., 2007; Szidat et al., 2009).

Generally, measurements made in urban areas have lower percentages of contemporary carbon in fine PM compared to those made in rural and remote sites due to local emissions from fossil-fuel combustion (e.g. Schichtel et al., 2008; Glasius et al., 2010). However, in some areas meat cooking (Schauer and Cass, 2000) and residential wood combustion (e.g. Gelencsér et al., 2007) may contribute to contemporary carbon during certain periods. As expected, modern sources of carbon dominate $\mathrm{PM}_{2.5}$ in rural areas with fractions of 0.75 to 0.95 for the US (Bench et al., 2007) and 0.63 to 0.76 for Europe (Gelencsér et al., 2007). However, high contributions of contemporary carbon to fine PM (0.46 to 0.90$)$ are also observed in urban areas during summer. In several cities in Europe, Japan and the western U.S. about half of the carbon in fine PM is contemporary, while higher values are found in south-eastern US cities (Lewis et al., 2004; Szidat et al., 2004; Lewis and Stiles, 2006; Bench et al., 2007; Takahashi et al., 2007; Szidat et al., 2009). Schichtel et al. (2008) examined measurements at paired rural and urban sites, and found urban contributions (above regional background levels) to contemporary carbon in $\mathrm{PM}_{2.5}$ of $0.23 \mu \mathrm{g} \mathrm{C} / \mathrm{m}^{3}$ (or $11 \%$ ) in north-west USA and $0.42 \mu \mathrm{g} \mathrm{C} / \mathrm{m}^{3}$ (or $17 \%$ ) in south-west USA during summer, when residential wood combustion is expected to be of minor significance.

However, this contribution was calculated by simply comparing the values at the two sites, and no allowance was made for wind direction. During periods when the wind was blowing from the urban to the rural site, the measured OA 
at the rural site would be greater than the background OA, and urban contribution calculated would be too low. On the other hand, slightly higher temperatures (and corresponding volatilisation of particulate matter) in urban areas could lead to a very slight lowering of the calculated urban contribution. It is difficult to determine whether any of this urban contribution is the result of an urban enhancement of natural organic aerosol or not, since a quantitative source apportionment was not performed in this study.

Pyrogenic carbon particles sampled in the Amazon, thought to be emitted by biomass or fossil fuel combustion, were examined by Pöschl et al. (2010) and found to have a partial organic coating. Q. Chen et al. (2009) found that the organic loading in the Amazon basin increased by $50 \%$, during periods with substantial influence of out of-Basin-air masses, although it is difficult to quantify what fraction of this organic aerosol was formed locally. Both of these observations qualitatively support an anthropogenic enhancemnent effect.

In the work of Szidat et al. (2009), sources of contemporary and fossil carbon were investigated by combining individual ${ }^{14} \mathrm{C}$ measurements of organic carbon, water-insoluble organic carbon, and elemental carbon with a bottom-up approach using levoglucosan as an organic tracer for biomass combustion. Comparing measurements from an urban area and a rural site, located $35 \mathrm{~km}$ apart, they showed an enhancement (by a factor of 2-3) of non-combustion related modern OC in aerosols from the urban site. These measurements suggest an enhancement of biological SOA due to interaction with anthropogenic emissions. Unfortunately measurements were not made at the rural site in summer.

An urban tracer and SOA formation modelling analysis was carried out on the data collected during the New England Air Quality Study (NEAQS) 2002, leading to the conclusion that the dominant fraction of the organic carbon aerosol could be attributed to anthropogenic secondary aerosol formation (de Gouw et al., 2005). This conclusion was based on the findings that firstly, air masses which showed high toluene/benzene ratios (indicating that little processing had taken place) had no subsequent peak in the organic carbon aerosol concentration. Secondly, when sampling took place off of the coast of Maine, where monoterpene emissions are high, no increase in the OA was observed and OA concentrations correlated with those of isopropyl nitrate, an anthropogenic VOC. This latter observation is consistent with an anthropogenic control of SOA even in a region with very high biogenic emissions.

A similar analysis was applied to data collected by aeroplane and ship during NEAQS-ITCT (New England Air Quality Study - Intercontinental Transport and Chemical Transformation) 2004 (de Gouw et al., 2008). The aircraft tracked a plume originating in New York City, which contained biogenic and anthropogenic VOCs, for two days. The concentrations of $\mathrm{CO}$ and WSOC were well correlated throughout the observational period, indicating the ur- ban air masses contained more WSOC than ambient air $\Delta \mathrm{WSOC} / \triangle \mathrm{CO}$ ratios increased by a factor of two by the second day and were considerably higher than those for primary emissions of organic carbon, suggesting the contribution of primary organic matter was low. However, even when using published particulate yields for low $\mathrm{NO}_{\mathrm{x}}$ conditions (Ng et al., 2007), the measured concentrations of the anthropogenic VOCs could only explain around $37 \%$ of the observed growth of the organic carbon aerosol, and the biogenic VOCs could explain less than $10 \%$. The authors speculate that the yields derived from chamber measurements may be lower than those in the real atmosphere, that the observed SOA could have been formed by VOCs which were not measured, or that SOA formation from biogenic precursors is more efficient in urban plumes.

In another study Weber et al. (2007) used measurements of WSOC as an estimate of SOA mass. They found high correlations between WSOC and anthropogenic emissions, such as isopropyl nitrate and carbon monoxide, in urban plumes originating in both Atlanta and New York City, during NEAQS-ITCT 2004. This suggested a strong linkage between WSOC (or SOA) and anthropogenic emissions. Interestingly, the ratios of anthropogenic VOCs to WSOC were similar in Atlanta and New York City, even though biogenic VOC concentrations were 10 to 100 times higher in Atlanta. This indicates that the mechanisms for SOA formation in Atlanta and New York City were similar, regardless of the much higher concentrations of biogenic VOCs in Atlanta, and that the process was strongly linked to anthropogenic emissions. However, ${ }^{14} \mathrm{C}$ analysis performed on WSOC extracted from filter samples collected during the same summer of 2004 in Atlanta showed that 70 to $80 \%$ of WSOC was biogenic in origin. This is consistent with biogenic VOCs being involved in most of the SOA formation. Remote sensing data was presented by Goldstein et al. (2009), showing an increase in summertime aerosol optical thickness (AOT) over southeastern USA. They demonstrate that the AOT increase is consistent with secondary aersol formed from BVOC, and suggest that the formation of this SOA is modulated by anthropogenic emissions.

The results from these studies suggest that it is possible that the incorporation of biogenic species into organic aerosol is more efficient in polluted air.

${ }^{14} \mathrm{C}$ analysis would suggest that most of the SOA is modern, however these measurements seem to disagree with other experimental evidence. A possible explanation may be that most ${ }^{14} \mathrm{C}$ measurements have been performed on bulk filters rather than on different fractions of the organic aerosol. Interestingly, the work of Weber et al. (2007) is one of the few studies to perform ${ }^{14} \mathrm{C}$ analysis on only the WSOC (not the total organic carbon) and yet they observed similar results to studies (e.g., Lemire et al., 2002; Lewis et al., 2004; Lewis and Stiles, 2006) using ${ }^{14} \mathrm{C}$ measurements from bulk filter samples. It should be noted that the partitioning of semivolatiles on filter samples may differ from the 
Table 3. The pre-industrial and present day burdens of SOA calculated in several modelling studies. The abbreviations in the last column are as follows: $\mathrm{Ox}$ - change in atmospheric oxidants, $\mathrm{APOA}$ - changes in anthropogenic POA, BPOA - changes in biogenic POA, $\mathrm{NO}_{\mathrm{x}}-\mathrm{NO}_{\mathrm{x}}$ effect on SOA yields, BVOC-changed BVOC emissions since pre-industrial period. For a full description of the models, see the individual papers.

\begin{tabular}{lllll}
\hline Study & $\begin{array}{l}\text { Preindustrial } \\
\text { burden of SOA (Tg) }\end{array}$ & $\begin{array}{l}\text { Present day } \\
\text { burden of SOA }(\mathrm{Tg})\end{array}$ & $\begin{array}{l}\text { Change } \\
\mathrm{Tg}(\%)\end{array}$ & $\begin{array}{l}\text { Effects } \\
\text { accounted for }\end{array}$ \\
\hline $\begin{array}{l}\text { Chung and Seinfeld (2002) } \\
\text { Tsigaridis et al. (2006) }\end{array}$ & 0.06 & 0.19 & $0.13(216 \%)$ & Ox,APOA,BPOA \\
$\begin{array}{l}\text { Hoyle et al. (2009) } \\
\text { Liao and Seinfeld (2005) } \\
\text { (baseline scenario) }\end{array}$ & 0.64 & 0.8 & $0.16(25 \%)$ & Ox,APOA,BVOC, NO, BPOA \\
\hline
\end{tabular}

atmosphere or change during sampling, resulting in positive or negative biases for these compounds.

The possibility cannot be ruled out that biogenic VOCs which are not accounted for in the plume modelling studies provide at least some of the missing biogenic OA mass. Another factor which would lead to higher modern SOA fractions, while maintaining a correlation with anthropogenic tracers, is an anthropogenic enhancement of SOA formation from naturally emitted BVOC.

\subsection{Large scale modelling of the anthropogenic contribution}

All global modelling studies examining the change in SOA burden since pre-industrial times show an increase in BSOA due to anthropogenic emissions (Table 3).

Anthropogenic VOC were not included as SOA precursors in Chung and Seinfeld (2002), however, the percentage of the present day SOA burden resulting directly from anthropogenic VOC was approximately $6 \%$ in Tsigaridis et al. (2006) and $8 \%$ in the experiments described in Hoyle et al. (2009). Thus, in each of these studies, the majority of the SOA increase since pre-industrial times is due to an enhancement of SOA formation from biogenic precursors due to changes in SOA partitioning, oxidation patterns and deposition rates. The contributions of biogenic and anthropogenic sources in Liao and Seinfeld (2005) were not listed separately.

The global distribution of the change in SOA from Hoyle et al. (2009) is shown in Fig. 4. The total increase in SOA since the pre-industrial period was modelled by performing two experiments in which the only difference was in the anthropogenic emissions. The total change in SOA column burden is shown in panel A. The largest tropospheric column increases are found near industrialized areas or in areas with large amounts of biomass burning. SOA burdens decrease at high southern latitudes and over eastern Russia, due to changes in SOA partitioning, oxidation and deposition patterns and due to lower biomass-burning emissions in the present day inventory than in the pre-industrial inventory, re-

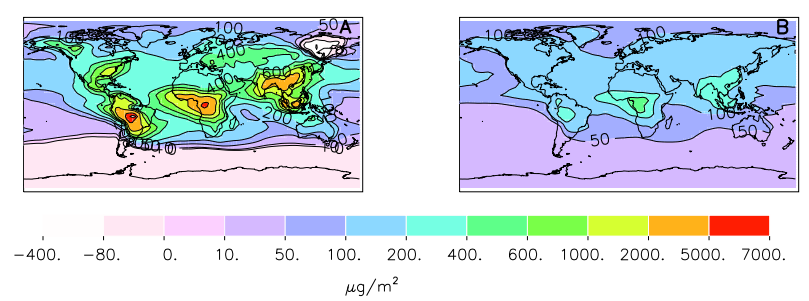

Fig. 4. (A) shows the modelled total column increase in SOA since the pre-industrial period, while $(\mathbf{B})$ shows the mass formed directly from anthropogenic SOA precursors.

spectively. Panel B shows the contribution to the total SOA increase from aromatic species predominantly emitted during fossil-fuel combustion, but also emitted during biomass burning. Maximum SOA burdens from these mostly anthropogenic SOA precursors are lower than $600 \mu \mathrm{g} / \mathrm{m}^{2}$, even over industrialised areas. The vast majority of the modelled increase in SOA formation is due to anthropogenic enhancement of SOA formation from biogenic precursors, in this case mainly by the provision of additional low volatility POA, which shifts the partitioning of secondary organic species in the model towards the condensed phase. The annual global emissions of POA in Hoyle et al. (2009) increased from $10.3 \mathrm{Tg}(\mathrm{C}) / \mathrm{yr}$ for the pre-industrial period to $30.4 \mathrm{Tg}(\mathrm{C}) / \mathrm{yr}$ for the present day model run. Predictions of future changes in SOA burdens are generally consistent with this effect, for example Heald et al. (2008) predict a $10 \%$ increase in SOA from monoterpene sources with a $60 \%$ increase in anthropogenic POA emissions between the years 2000 and 2100, while Liao et al. (2006) predict a 31\% increase in SOA from 2000 to 2100 as POA emissions more than double during this period.

In such models, the partitioning of SOA is based on the Pankow/Odum (Pankow, 1994; Odum et al., 1996) framework, and thus corresponds with chamber measurements of SOA partitioning. Models generally contain a single organic condensed phase, combining both SOA and hydrophilic 
POA. The applicability of this single phase for partitioning calculations is discussed in Sect. 2.1. Tsigaridis et al. (2006) found that accounting for the $\mathrm{VOC} / \mathrm{NO}_{\mathrm{x}}$ ratio on the production of SOA resulted in a $20 \%$ decrease in BSOA globally and a $20 \%$ increase in ASOA.

The effect of anthropogenic emissions on the formation of BSOA was investigated by Carlton et al. (2010), using the CMAQ regional model. They found that the SOA burden on the east coast of the USA was reduced, at the surface, by about $50 \%$ if all controllable non-natural emissions were shut off. The greatest reductions in BSOA were achieved by removing anthropogenic POA $(-30 \%), \mathrm{NO}_{\mathrm{x}}(-20 \%)$ and reactive non methane carbon species $(-10 \%)$. However, the modelling study was only carried out for the time period of 15 August-4 September, 2003, and therefore represents a time period where high concentrations of natural VOC are expected.

As the dominant sink of SOA precursor VOC is oxidation followed by deposition (Chung and Seinfeld, 2002), the distribution of oxidants plays a role in determining the SOA burden. If the concentration of atmospheric oxidants increases, the VOCs are oxidised closer to the surface and their source regions, resulting in faster removal, and a shorter SOA lifetime. When the total global burden of SOA increases, such processes can lead to a greater increase in SOA in the boundary layer than in the upper troposphere (Tsigaridis et al., 2006), or even to lower SOA burdens in the upper troposphere, and in remote regions (Chung and Seinfeld, 2002; Hoyle et al., 2009). The opposite effect is seen when emissions of VOC are so large that the oxidant concentrations are depleted. In these areas, the concentration of SOA is lower and the precursor VOC are transported further from their source (Heald et al., 2008). Global models therefore predict a change in the distribution and lifetime of SOA.

An increase in the global burden of SOA of $36 \%$ by 2100 was predicted by Heald et al. (2008), using the A1B emissions from the IPCC Special Report on Emissions Scenario (SRES), primarily due to increases in biogenic and anthropogenic emissions. However, an experiment examining only the effects of land use change found a $14 \%$ decrease in global SOA, mainly due to cropland expansion. Other studies have predicted a $54 \%$ increase in SOA by 2100 , using the A2 scenario (Liao et al., 2006) - (a 31\% increase was found when only the anthropogenic emissions were changed to projected 2100 values), and a doubling of SOA (Tsigaridis and Kanakidou, 2007), due to changes in emissions, using the IS92a scenario. J. Chen et al. (2009) examine the change in BVOC emissions in the USA, between the present and ca. 20452054. They find increases in monoterpene and isoprene emissions of $26 \%$ and $20 \%$ respectively, due to increases in temperature and solar insolation. When land use change was coupled with climate change, the isoprene and monoterpene emissions were found to reduce by $52 \%$ and $31 \%$ respectively. Similarly to Heald et al. (2008), the reduction was attributed to crop land expansion. The effect of shorter term variability in temperature and moisture on SOA was evaluated over a decade by Tsigaridis et al. (2005), who found an associated SOA production variation of around 8\%, which is equal to their calculated production of ASOA. Changes in BVOC emissions and in deposition of SOA were both found to contribute to the variability.

\section{Summary and conclusion}

The biosphere is undoubtedly the major source of VOC in the atmosphere, however the research discussed here shows that the anthropogenic modification of this source is significant. Anthropogenic VOC and particulate emissions contribute directly to the total OA burden, both in, and downwind of urban areas. On the other hand, the enhancement, through anthropogenic emissions, of SOA formation from true biogenic precursors is currently a poorly characterised effect. We define this enhanced SOA fraction, eBSOA, as that fraction of SOA which is produced from modern (non-fossil), naturally emitted biogenic organic compounds, which would not be in the condensed phase in the absence of anthropogenic effects. Emissions from biofuel combustion, cooking, and humaninitiated biomass burning do not contribute directly to eBSOA, these are rather direct sources of anthropogenic semi volatile organic compounds and aerosols. Changes in BVOC emissions due to changes in land use, climate or atmospheric composition should be considered as contributing to eBSOA.

The importance of eBSOA lies in the fact that it must be considered an anthropogenic contribution to the aerosol burden, while it does not directly consist of species emitted via human activity.

We describe several mechanisms by which anthropogenic modification of the atmosphere may affect the formation of SOA from biogenic compounds, however, to date, these effects have been poorly quantified. In the equilibrium gas/particle partitioning framework, an increase in aerosol leads to a shift in partitioning from the gas to the condensed phase, therefore increased anthropogenic emissions of organic particulate matter or semi-volatile OC may lead to a shift of biogenic carbon from the gas to the condensed phase. The magnitude of this effect depends on the miscibility of the condensed and gas phase species, a quantity that is extremely variable between different compounds, and not well described for atmospherically relevant mixtures. A further complication is the formation of different liquid phases within the same aerosol droplet. Condensed phase reactions have been shown to reduce the volatility of organic species once they partition to the aerosol, and the efficiency of these reactions depends on the aerosol composition or acidity.

Anthropogenic emissions of $\mathrm{NO}_{\mathrm{x}}$ can greatly affect yields of SOA, but again the total effect depends on the organic species involved. A comparison of the yields from different experiments is difficult due to the dependence of yield on the concentration of the organic species. 
The formation of new particles in the atmosphere can occur both due to organic species or sulphuric acid. Gas phase organics certainly partition to the newly formed particles, being responsible for much of their growth (Kulmala et al., 2001; Bonn et al., 2008; Boy et al., 2008). Thus new particle formation may be an important SOA formation mechanism. Because of the role of sulphuric acid in new particle formation, changes in emissions of sulphur compounds may lead to changes in SOA concentrations.

A general approach for isolating the eBSOA contribution to the observed OA burden was outlined, taking advantage of various measurement techniques to apportion the carbon to sources, based on properties such as age and correlation with other tracers.

The evidence for substantial contributions of eBSOA to the OA burden in existing measurements was discussed.

Most large scale modelling studies show a clear contribution of eBSOA to the increase in SOA since pre-industrial times, for example only $31 \%$ and $21 \%$ of the modelled SOA increase consisted of SOA formed directly from anthropogenic VOC in the studies of Tsigaridis et al. (2006) and Hoyle et al. (2009) respectively, the vast majority of the remainder being eBSOA. An eBSOA contribution of around $50 \%$ is estimated by Carlton et al. (2010) for the east coast of the USA in summer. Changes in temperature, precipitation, atmospheric composition, and land usage all affect the emissions of BVOC, and have been predicted to lead to substantial changes in BSOA in the future.

However, despite the multitude of mechanisms possible for eBSOA formation, the evidence from current observations is less clear. Modern carbon certainly accounts for large fractions of the urban OA burden, even in summer (Lewis et al., 2004; Bench et al., 2007), when anthropogenic emissions of modern carbon, for example through wood burning, should be relatively low. However, there may be other substantial urban sources of modern OA. More direct evidence is found in the comparison of measurements at closely located urban and rural sites, where for example the measurements of Szidat et al. (2009) would suggest the contribution of eBSOA to the observed OC mass concentration could be around $50-60 \%$. Detailed modelling of OA in urban plumes (e.g. de Gouw et al., 2008) cannot account for the observed OA mass, and although there are several possible reasons for this, such as unknown biogenic OC species, eBSOA may help to explain some of the discrepancy.

More work is needed, both with respect to the theoretical understanding of mechanisms leading to eBSOA, and its detection in the atmosphere in order to better quantify the contribution of eBSOA to the OA burden.

The partitioning of biogenic semi-volatile organic species to atmospherically relevant aerosols needs to be better characterised. Such aerosols include, for example, SOA from mixtures of anthropogenic and/or biogenic precursors, POA from different sources, chemically aged POA, and soot. The effect of anthropogenic emissions on condensed phase re- actions, and thus on the partitioning of biogenic species, also needs to be better quantified, including the effect of aerosol acidity. In this respect, more measurements of ambient aerosol are needed, which aim specifically to relate SOA burden to aerosol acidity, under the exclusion of other effects which have until now lead to some ambiguity.

The net effect of $\mathrm{NO}_{\mathrm{x}}$ on yields of SOA from mixtures of biogenic precursors needs to be systematically assessed, not only for different $\mathrm{VOC} / \mathrm{NO}_{\mathrm{x}}$ ratios, but for different $\mathrm{VOC}$ concentrations, so that the yields are known for the range of conditions encountered in the atmosphere.

The mechanisms behind new particle formation in the atmosphere need to be better understood, in particular the relative roles of different species such as sulphuric acid or organic species, in polluted and non-polluted environments, and the dependence of particle formation rates on the concentrations of these compounds. The effect of changes in new particle formation on the burden and lifetime of SOA, and on the numbers of $\mathrm{CCN}$ needs to be assessed.

More systematic regional or global modelling studies with a fully coupled biosphere and atmosphere would be extremely useful to better quantify the magnitude of the changes in BVOC emissions resulting from climate change, land use change, or atmospheric composition change. An investigation of possible climate feedbacks through the direct or indirect effect of organic aerosols would likewise be very interesting.

More effort needs to be made to quantify, or at least constrain, the proportion of eBSOA in the observed atmospheric OA burden. As there is no specific marker for eBSOA, this task can only be achieved by the apportionment of the observed OA mass to its various sources. To this end, measurements upstream, within and downstream of urban areas are required, where the enhancement of the urban OA over the regional background can be determined, and where the contribution of anthropogenic VOC emissions can be removed based on the age of carbon and the correlation with markers of specific emission sources. More work is needed to characterise the changes in ratios of these molecular markers to $\mathrm{OA}$ as a function of time from emission.

Acknowledgements. The authors acknowledge the following agencies, sponsors of the US/Nordic Workshop Series on Improved Aerosol Understanding: US National Science Foundation; the Nordic Center of Excellence: Biosphere-Atmosphere-CloudClimate Interactions; the University of Helsinki, Finland; and the International Meteorological Institute, Stockholm, Sweden. CRH was partially supported by Swiss National Science Foundation grant number 200021_120175/1. The authors thank Uwe Weers for the design of Fig. 2.

Edited by: R. Holzinger 


\section{References}

Adams, P. J., Seinfeld, J. H., Koch, D., Mickley, L., and Jacob, D.: General circulation model assessment of direct radiative forcing by the sulfate-nitrate-ammonium-water inorganic aerosol system, J. Geophys. Res.-Atmos., 106, 1097-1111, 2001.

Aiken, A. C., Salcedo, D., Cubison, M. J., Huffman, J. A., DeCarlo, P. F., Ulbrich, I. M., Docherty, K. S., Sueper, D., Kimmel, J. R., Worsnop, D. R., Trimborn, A., Northway, M., Stone, E. A., Schauer, J. J., Volkamer, R. M., Fortner, E., de Foy, B., Wang, J., Laskin, A., Shutthanandan, V., Zheng, J., Zhang, R., Gaffney, J., Marley, N. A., Paredes-Miranda, G., Arnott, W. P., Molina, L. T., Sosa, G., and Jimenez, J. L.: Mexico City aerosol analysis during MILAGRO using high resolution aerosol mass spectrometry at the urban supersite (T0) - Part 1: Fine particle composition and organic source apportionment, Atmos. Chem. Phys., 9, 66336653, doi:10.5194/acp-9-6633-2009, 2009.

Albrecht, B. A.: Aerosols, Cloud Microphysics, and Fractional Cloudiness, Science, 245, 1227-1230, 1989.

Allan, J. D., Alfarra, M. R., Bower, K. N., Coe, H., Jayne, J. T., Worsnop, D. R., Aalto, P. P., Kulmala, M., Hyötyläinen, T., Cavalli, F., and Laaksonen, A.: Size and composition measurements of background aerosol and new particle growth in a Finnish forest during QUEST 2 using an Aerodyne Aerosol Mass Spectrometer, Atmos. Chem. Phys., 6, 315-327, doi:10.5194/acp-6-315-2006, 2006.

Allan, J. D., Williams, P. I., Morgan, W. T., Martin, C. L., Flynn, M. J., Lee, J., Nemitz, E., Phillips, G. J., Gallagher, M. W., and Coe, H.: Contributions from transport, solid fuel burning and cooking to primary organic aerosols in two UK cities, Atmos. Chem. Phys., 10, 647-668, doi:10.5194/acp-10-647-2010, 2010.

Andrews, E., Saxena, P., Musarra, S., Hildemann, L. M., Koutrakis, P., McMurry, P. H., Olmez, I., and White, W. H.: Concentration and composition of atmospheric aerosols from the 1995 SEAVS experiment and a review of the closure between chemical and gravimetric measurements, J. Air Waste Manage. Assoc., 50, 648-664, 2000.

Artaxo, P. and Hansson, H. C.: Size Distribution of Biogenic Aerosol-Particles from the Amazon Basin, Atmos. Environ., 29, 393-402, 1995.

Artaxo, P., Maenhaut, W., Storms, H., and Vangrieken, R.: Aerosol Characteristics and Sources for the Amazon Basin during the Wet Season, J. Geophys. Res.-Atmos., 95, 16971-16985, 1990.

Asa-Awuku, A., Miracolo, M. A., Kroll, J. H., Robinson, A. L., and Donahue, N. M.: Mixing and phase partitioning of primary and secondary organic aerosols, Geophys. Res. Lett., 36, L15827, doi:10.1029/2009g1039301, 2009.

Baduel, C., Voisin, D., and Jaffrezo, J.-L.: Seasonal variations of concentrations and optical properties of water soluble HULIS collected in urban environments, Atmos. Chem. Phys., 10, 40854095, doi:10.5194/acp-10-4085-2010, 2010.

Baltensperger, U., Kalberer, M., Dommen, J., Paulsen, D., Alfarra, M. R., Coe, H., Fisseha, R., Gascho, A., Gysel, M., Nyeki, S., Sax, M., Steinbacher, M., Prevot, A. S. H., Sjoren, S., Weingartner, E., and Zenobi, R.: Secondary organic aerosols from anthropogenic and biogenic precursors, Faraday Discuss., 130, 265-278, 2005.

Barsanti, K. C. and Pankow, J. F.: Thermodynamics of the formation of atmospheric organic particulate matter by accretion reactions - Part 1: aldehydes and ketones, Atmos Environ., 38, 4371-
4382, 2004.

Behera, S. N. and Sharma, M.: Reconstructing Primary and Secondary Components of PM2.5 Composition for an Urban Atmosphere, Aerosol Sci. Technol., 44(11), 983-992, doi:10.1080/02786826.2010.504245, 2010.

Bench, G., Fallon, S., Schichtel, B., Malm, W., and McDade, C.: Relative contributions of fossil and contemporary carbon sources to PM 2.5 aerosols at nine Interagency Monitoring for Protection of Visual Environments (IMPROVE) network sites, J. Geophys. Res.-Atmos., 112, D10205, doi:10.1029/2006jd007708, 2007.

Bonn, B., Kulmala, M., Riipinen, I., Sihto, S. L., and Ruuskanen, T. M.: How biogenic terpenes govern the correlation between sulfuric acid concentrations and new particle formation, J. Geophys. Res.-Atmos., 113, D12209, doi:10.1029/2007jd009327, 2008.

Bonn, B., Boy, M., Kulmala, M., Groth, A., Trawny, K., Borchert, S., and Jacobi, S.: A new parametrization for ambient particle formation over coniferous forests and its potential implications for the future, Atmos. Chem. Phys., 9, 8079-8090, doi:10.5194/acp-9-8079-2009, 2009.

Boy, M., Rannik, U., Lehtinen, K. E. J., Tarvainen, V., Hakola, H., and Kulmala, M.: Nucleation events in the continental boundary layer: Long-term statistical analyses of aerosol relevant characteristics, J. Geophys. Res.-Atmos., 108, 4667, doi:10.1029/2003jd003838, 2003.

Boy, M., Karl, T., Turnipseed, A., Mauldin, R. L., Kosciuch, E., Greenberg, J., Rathbone, J., Smith, J., Held, A., Barsanti, K., Wehner, B., Bauer, S., Wiedensohler, A., Bonn, B., Kulmala, M., and Guenther, A.: New particle formation in the Front Range of the Colorado Rocky Mountains, Atmos. Chem. Phys., 8, 15771590, doi:10.5194/acp-8-1577-2008, 2008.

Brown, S. S., deGouw, J. A., Warneke, C., Ryerson, T. B., Dubé, W. P., Atlas, E., Weber, R. J., Peltier, R. E., Neuman, J. A., Roberts, J. M., Swanson, A., Flocke, F., McKeen, S. A., Brioude, J., Sommariva, R., Trainer, M., Fehsenfeld, F. C., and Ravishankara, A. R.: Nocturnal isoprene oxidation over the Northeast United States in summer and its impact on reactive nitrogen partitioning and secondary organic aerosol, Atmos. Chem. Phys., 9, 30273042, doi:10.5194/acp-9-3027-2009, 2009.

Burkholder, J. B., Baynard, T., Ravishankara, A. R., and Lovejoy, E. R.: Particle nucleation following the $\mathrm{O}-3$ and $\mathrm{OH}$ initiated oxidation of alpha-pinene and beta-pinene between 278 and 320 K, J. Geophys. Res.-Atmos., 112, D10216, doi:10.1029/2006jd007783, 2007.

Carlton, A. G., Wiedinmyer, C., and Kroll, J. H.: A review of Secondary Organic Aerosol (SOA) formation from isoprene, Atmos. Chem. Phys., 9, 4987-5005, doi:10.5194/acp-9-4987-2009, 2009.

Carlton, A. G., Pinder, R. W., Bhave, P. V., and Pouliot, G. A.: To What Extent Can Biogenic SOA be Controlled?, Environ. Sci. Technol., 44, 3376-3380, 2010.

Chan, A. W. H., Chan, M. N., Surratt, J. D., Chhabra, P. S., Loza, C. L., Crounse, J. D., Yee, L. D., Flagan, R. C., Wennberg, P. O., and Seinfeld, J. H.: Role of aldehyde chemistry and NOx concentrations in secondary organic aerosol formation, Atmos. Chem. Phys., 10, 7169-7188, doi:10.5194/acp-10-7169-2010, 2010a.

Chan, M. N., Surratt, J. D., Claeys, M., Edgerton, E. S., Tanner, R. L., Shaw, S. L., Zheng, M., Knipping, E. M., Eddingsaas, N. C., Wennberg, P. O., and Seinfeld, J. H.: Characterization and Quantification of Isoprene-Derived Epoxydiols in Ambient 
Aerosol in the Southeastern United States, Environ. Sci. Technol., 44, 4590-4596, doi:10.1021/es100596b, 2010b.

Charlson, R. J., Schwartz, S. E., Hales, J. M., Cess, R. D., Coakley, J. A., Hansen, J. E., and Hofmann, D. J.: Climate Forcing by Anthropogenic Aerosols, Science, 255, 423-430, 1992.

Chen, J., Avise, J., Guenther, A., Wiedinmyer,C., Salathe, E., Jackson, R. B., and Lamb, B.: Future land use and land cover influences on regional biogenic emissions and air quality in the United States, Atmos. Environ., 43, 5771-5780, doi:10.1016/j.atmosenv.2009.08.015, 2009.

Chen, Q., Farmer, D. K., Schneider, J., Zorn, S. R., Heald, C. L., Karl, T. G., Guenther, A., Allan, J. D., Robinson, N., Coe, H., Kimmel, J. R., Pauliquevis, T., Borrmann, S., Poschl, U., Andreae, M. O., Artaxo, P., Jimenez, J. L., and Martin, S. T.: Mass spectral characterization of submicron biogenic organic particles in the Amazon Basin, Geophys. Res. Lett., 36, L20806, doi:10.1029/2009g1039880, 2009.

Chow, J. C., Watson, J. G., Fujita, E. M., Lu, Z. Q., Lawson, D. R., and Ashbaugh, L. L.: Temporal and spatial variations of $\operatorname{PM(2.5)}$ and PM(10) aerosol in the Southern California air-quality study, Atmos. Environ., 28, 2061-2080, 1994.

Chuang, C. C., Penner, J. E., Taylor, K. E., Grossman, A. S., and Walton, J. J.: An assessment of the radiative effects of anthropogenic sulfate, J. Geophys. Res.-Atmos., 102, 3761-3778, 1997.

Chung, S. H. and Seinfeld, J. H.: Global distribution and climate forcing of carbonaceous aerosols, J. Geophys. Res.-Atmos., 107, 4407, doi:10.1029/2001jd001397, 2002.

Claeys, M., Graham, B., Vas, G., Wang, W., Vermeylen, R., Pashynska, V., Cafmeyer, J., Guyon, P., Andreae, M. O., Artaxo, P., and Maenhaut, W.: Formation of secondary organic aerosols through photooxidation of isoprene, Science, 303, 1173-1176, 2004a.

Claeys, M., Wang, W., Ion, A., Kourtchev, I., Gelencser, A., and Maenhaut, W.: Formation of secondary organic aerosols from isoprene and its gas-phase oxidation products through reaction with hydrogen peroxide, Atmos. Environ., 38, 4093-4098, doi:10.1016/j.atmosenv.2004.06.001, 2004b.

Corrigan, C. E. and Novakov, T.: Cloud condensation nucleus activity of organic compounds: a laboratory study, Atmos. Environ., 33, 2661-2668, 1999.

de Gouw, J. A., Middlebrook, A. M., Warneke, C., Goldan, P. D., Kuster, W. C., Roberts, J. M., Fehsenfeld, F. C., Worsnop, D. R., Canagaratna, M. R., Pszenny, A. A. P., Keene, W. C., Marchewka, M., Bertman, S. B., and Bates, T. S.: Budget of organic carbon in a polluted atmosphere: Results from the New England Air Quality Study in 2002, J. Geophys. Res.-Atmos., 110, D16305, doi:10.1029/2004jd005623, 2005.

de Gouw, J. A., Brock, C. A., Atlas, E. L., Bates, T. S., Fehsenfeld, F. C., Goldan, P. D., Holloway, J. S., Kuster, W. C., Lerner, B. M., Matthew, B. M., Middlebrook, A. M., Onasch, T. B., Peltier, R. E., Quinn, P. K., Senff, C. J., Stohl, A., Sullivan, A. P., Trainer, M., Warneke, C., Weber, R. J., and Williams, E. J.: Sources of particulate matter in the northeastern United States in summer: 1. Direct emissions and secondary formation of organic matter in urban plumes, J. Geophys. Res.-Atmos., 113, D08301, doi:10.1029/2007jd009243, 2008.

DeCarlo, P. F., Dunlea, E. J., Kimmel, J. R., Aiken, A. C., Sueper, D., Crounse, J., Wennberg, P. O., Emmons, L., Shinozuka, Y., Clarke, A., Zhou, J., Tomlinson, J., Collins, D. R., Knapp, D.,
Weinheimer, A. J., Montzka, D. D., Campos, T., and Jimenez, J. L.: Fast airborne aerosol size and chemistry measurements above Mexico City and Central Mexico during the MILAGRO campaign, Atmos. Chem. Phys., 8, 4027-4048, doi:10.5194/acp8-4027-2008, 2008.

DeCarlo, P. F., Ulbrich, I. M., Crounse, J., de Foy, B., Dunlea, E. J., Aiken, A. C., Knapp, D., Weinheimer, A. J., Campos, T., Wennberg, P. O., and Jimenez, J. L.: Investigation of the sources and processing of organic aerosol over the Central Mexican Plateau from aircraft measurements during MILAGRO, Atmos. Chem. Phys., 10, 5257-5280, doi:10.5194/acp-10-52572010, 2010.

Docherty, K. S., Stone, E. A., Ulbrich, I. M., DeCarlo, P. F., Snyder, D. C., Schauer, J. J., Peltier, R. E., Weber, R. J., Murphy, S. M., Seinfeld, J. H., Grover, B. D., Eatough, D. J., and Jimenez, J. L.: Apportionment of Primary and Secondary Organic Aerosols in Southern California during the 2005 Study of Organic Aerosols in Riverside (SOAR-1), Environ. Sci. Technol., 42, 7655-7662, 2008.

Dommen, J., Metzger, A., Duplissy, J., Kalberer, M., Alfarra, M. R., Gascho, A., Weingartner, E., Prevot, A. S. H., Verheggen, B., and Baltensperger, U.: Laboratory observation of oligomers in the aerosol from isoprene/NOx photooxidation, Geophys. Res. Lett., 33, L13805, doi:10.1029/2006g1026523, 2006.

Donahue, N. M., Robinson, A. L., Stanier, C. O., and Pandis, S. N.: Coupled partitioning, dilution, and chemical aging of semivolatile organics, Environ. Sci. Technol., 40, 2635-2643, 2006a.

Donahue, N. M., Robinson, A. L., Stanier, C. O., and Pandis, S. N.: Coupled partitioning, dilution, and chemical aging of semivolatile organics, Environ. Sci. Technol., 40, 2635-2643, 2006 b.

Donahue, N. M., Robinson, A. L., and Pandis, S. N.: Atmospheric organic particulate matter: From smoke to secondary organic aerosol, Atmos. Environ., 43, 94-106, 2009.

Edney, E., Kleindienst, T., Jaoui, M., Lewandowski, M., Offenberg, J., Wang, W., and Claeys, M.: Formation of 2methyl tetrols and 2-methylglyceric acid in secondary organic aerosol from laboratory irradiated isoprene/NOX/SO2/air mixtures and their detection in ambient PM2.5 samples collected in the eastern United States, Atmos. Environ., 39, 5281-5289, doi:10.1016/j.atmosenv.2005.05.031, 2005.

Fine, P. M., Cass, G. R., and Simoneit, B. R. T.: Chemical characterization of fine particle emissions from fireplace combustion of woods grown in the northeastern United States, Environ. Sci. Technol., 35, 2665-2675, 2001.

Fine, P. M., Cass, G. R., and Simoneit, B. R. T.: Chemical characterization of fine particle emissions from the fireplace combustion of woods grown in the southern United States, Environ. Sci. Technol., 36, 1442-1451, 2002.

Fuzzi, S., Andreae, M. O., Huebert, B. J., Kulmala, M., Bond, T. C., Boy, M., Doherty, S. J., Guenther, A., Kanakidou, M., Kawamura, K., Kerminen, V.-M., Lohmann, U., Russell, L. M., and Pöschl, U.: Critical assessment of the current state of scientific knowledge, terminology, and research needs concerning the role of organic aerosols in the atmosphere, climate, and global change, Atmos. Chem. Phys., 6, 2017-2038, doi:10.5194/acp-62017-2006, 2006.

Gelencsér, A., May, B., Simpson, D., Sanchez-Ochoa, A., Kasper- 
Giebl, A., Puxbaum, H., Caseiro, A., Pio, C., and Legrand, M.: Source apportionment of PM2.5 organic aerosol over Europe: Primary/secondary, natural/anthropogenic, and fossil/biogenic origin, J. Geophys. Res.-Atmos., 112, D23s04, doi:10.1029/2006jd008094, 2007.

Giebl, H., Berner, A., Reischl, G., Puxbaum, H., Kasper-Giebl, A., and Hitzenberger, R.: CCN activation of oxalic and malonic acid test aerosols with the University of Vienna cloud condensation nuclei counter, J. Aerosol Sci., 33, 1623-1634, 2002.

Glasius, M., Boel, C., Bruun, N., Easa, L. M., Hornung, P., Klausen, H. S., Klitgaard, K. C., Lindeskov, C., Moller, C. K., Nissen, H., Petersen, A. P. F., Kleefeld, S., Boaretto, E., Hansen, T. S., Heinemeier, J., and Lohse, C.: Relative contribution of biogenic and anthropogenic sources to formic and acetic acids in the atmospheric boundary layer, J. Geophys. Res.-Atmos., 106, 74157426, 2001.

Glasius, M., la Cour, A., and Lohse, C.: Contemporary and fossil carbon in fine particulate matter - a study in five European cities, in preparation, 2011.

Goldstein, A. H., Koven, C. D., Heald, C. L., and Fung, I. Y.: Biogenic carbon and anthropogenic pollutants combine to form a cooling haze over the southeastern United States, P. Natl. Acad. Sci. USA, 106(22), 8835-8840, 2009.

Graham, B., Mayol-Bracero, O. L., Guyon, P., Roberts, G. C., Decesari, S., Facchini, M. C., Artaxo, P., Maenhaut, W., Koll, P., and Andreae, M. O.: Water-soluble organic compounds in biomass burning aerosols over Amazonia - 1. Characterization by NMR and GC-MS, J. Geophys. Res.-Atmos., 107, 8047, doi:10.1029/2001jd000336, 2002.

Grieshop, A. P., Donahue, N. M., and Robinson, A. L.: Is the gas-particle partitioning in alpha-pinene secondary organic aerosol reversible?, Geophys. Res. Lett., 34, L14810, doi:10.1029/2007g1029987, 2007.

Grieshop, A. P., Donahue, N. M., and Robinson, A. L.: Laboratory investigation of photochemical oxidation of organic aerosol from wood fires 2: analysis of aerosol mass spectrometer data, Atmos. Chem. Phys., 9, 2227-2240, doi:10.5194/acp-9-2227-2009, 2009.

Griffin, R. J., Cocker, D. R., Flagan, R. C., and Seinfeld, J. H.: Organic aerosol formation from the oxidation of biogenic hydrocarbons, J. Geophys. Res.-Atmos., 104, 3555-3567, 1999.

Gustafsson, O., Krusa, M., Zencak, Z., Sheesley, R. J., Granat, L., Engstrom, E., Praveen, P. S., Rao, P. S. P., Leck, C., and Rodhe, H.: Brown Clouds over South Asia: Biomass or Fossil Fuel Combustion?, Science, 323, 495-498, 2009.

Hansen, J. E. and Sato, M.: Trends of measured climate forcing agents, P. Natl. Acad. Sci. USA, 98, 14778-14783, 2001.

Hays, M. D., Fine, P. M., Geron, C. D., Kleeman, M. J., and Gullett, B. K.: Open burning of agricultural biomass: Physical and chemical properties of particle-phase emissions, Atmos. Environ., 39, 6747-6764, 2005.

Heald, C. L., Henze, D. K., Horowitz, L. W., Feddema, J., Lamarque, J. F., Guenther, A., Hess, P. G., Vitt, F., Seinfeld, J. H., Goldstein, A. H., and Fung, I.: Predicted change in global secondary organic aerosol concentrations in response to future climate, emissions, and land use change, J. Geophys. Res.-Atmos., 113, D05211, doi:10.1029/2007jd009092, 2008.

Hennigan, C. J., Bergin, M. H., Russell, A. G., Nenes, A., and Weber, R. J.: Gas/particle partitioning of water-soluble or- ganic aerosol in Atlanta, Atmos. Chem. Phys., 9, 3613-3628, doi:10.5194/acp-9-3613-2009, 2009.

Hennigan, C. J., Sullivan, A. P., Collett Jr., J. L., and Robinson, A. L.: Levoglucosan stability in biomass burning particles exposed to hydroxyl radicals, Geophys. Res. Lett., 37, L09806, doi:10.1029/2010GL043088, 2010.

Hodzic, A., Jimenez, J. L., Madronich, S., Aiken, A. C., Bessagnet, B., Curci, G., Fast, J., Lamarque, J.-F., Onasch, T. B., Roux, G., Schauer, J. J., Stone, E. A., and Ulbrich, I. M.: Modeling organic aerosols during MILAGRO: importance of biogenic secondary organic aerosols, Atmos. Chem. Phys., 9, 6949-6981, doi:10.5194/acp-9-6949-2009, 2009.

Hoffmann, T., Odum, J. R., Bowman, F., Collins, D., Klockow, D., Flagan, R. C., and Seinfeld, J. H.: Formation of organic aerosols from the oxidation of biogenic hydrocarbons, J. Atmos. Chem., 26, 189-222, 1997.

Hoffmann, T., O’Dowd, C. D., and Seinfeld, J. H.: Iodine oxide homogeneous nucleation: An explanation for coastal new particle production, Geophys. Res. Lett., 28, 1949-1952, 2001.

Hoyle, C. R., Berntsen, T., Myhre, G., and Isaksen, I. S. A.: Secondary organic aerosol in the global aerosol - chemical transport model Oslo CTM2, Atmos. Chem. Phys., 7, 5675-5694, doi:10.5194/acp-7-5675-2007, 2007.

Hoyle, C. R., Myhre, G., Berntsen, T. K., and Isaksen, I. S. A.: Anthropogenic influence on SOA and the resulting radiative forcing, Atmos. Chem. Phys., 9, 2715-2728, doi:10.5194/acp-9-27152009, 2009.

Huang, X.-F., He, L.-Y., Hu, M., Canagaratna, M. R., Sun, Y., Zhang, Q., Zhu, T., Xue, L., Zeng, L.-W., Liu, X.-G., Zhang, Y.-H., Jayne, J. T., Ng, N. L., and Worsnop, D. R.: Highly time-resolved chemical characterization of atmospheric submicron particles during 2008 Beijing Olympic Games using an Aerodyne High-Resolution Aerosol Mass Spectrometer, Atmos. Chem. Phys., 10, 8933-8945, doi:10.5194/acp-10-8933-2010, 2010.

Huffman, J. A., Docherty, K. S., Mohr, C., Cubison, M. J., Ulbrich, I. M., Ziemann, P. J., Onasch, T. B., and Jimenez, J. L.: Chemically-Resolved Volatility Measurements of Organic Aerosol from Different Sources, Environ. Sci. Technol., 43, 5351-5357, 2009.

Iinuma, Y., Bruggemann, E., Gnauk, T., Muller, K., Andreae, M. O., Helas, G., Parmar, R., and Herrmann, H.: Source characterization of biomass burning particles: The combustion of selected European conifers, African hardwood, savanna grass, and German and Indonesian peat, J. Geophys. Res.-Atmos., 112, D08209, doi:10.1029/2006jd007120, 2007.

Jang, M. S., Czoschke, N. M., Lee, S., and Kamens, R. M.: Heterogeneous atmospheric aerosol production by acid-catalyzed particle-phase reactions, Science, 298, 814-817, 2002.

Jenk, T. M., Szidat, S., Schwikowski, M., Gggeler, H. W., Brütsch, S., Wacker, L., Synal, H.-A., and Saurer, M.: Radiocarbon analysis in an Alpine ice core: record of anthropogenic and biogenic contributions to carbonaceous aerosols in the past (1650-1940), Atmos. Chem. Phys., 6, 5381-5390, doi:10.5194/acp-6-53812006, 2006.

Jimenez, J. L., Canagaratna, M. R., Donahue, N. M., Prevot, A. S. H., Zhang, Q., Kroll, J. H., DeCarlo, P. F., Allan, J. D., Coe, H., Ng, N. L., Aiken, A. C., Docherty, K. S., Ulbrich, I. M., Grieshop, A. P., Robinson, A. L., Duplissy, J., Smith, J. D., Wil- 
son, K. R., Lanz, V. A., Hueglin, C., Sun, Y. L., Tian, J., Laaksonen, A., Raatikainen, T., Rautiainen, J., Vaattovaara, P., Ehn, M., Kulmala, M., Tomlinson, J. M., Collins, D. R., Cubison, M. J., Dunlea, E. J., Huffman, J. A., Onasch, T. B., Alfarra, M. R., Williams, P. I., Bower, K., Kondo, Y., Schneider, J., Drewnick, F., Borrmann, S., Weimer, S., Demerjian, K., Salcedo, D., Cottrell, L., Griffin, R., Takami, A., Miyoshi, T., Hatakeyama, S., Shimono, A., Sun, J. Y., Zhang, Y. M., Dzepina, K., Kimmel, J. R., Sueper, D., Jayne, J. T., Herndon, S. C., Trimborn, A. M., Williams, L. R., Wood, E. C., Middlebrook, A. M., Kolb, C. E., Baltensperger, U., and Worsnop, D. R.: Evolution of Organic Aerosols in the Atmosphere, Science, 326, 1525-1529, 2009.

Kanakidou, M., Seinfeld, J. H., Pandis, S. N., Barnes, I., Dentener, F. J., Facchini, M. C., Van Dingenen, R., Ervens, B., Nenes, A., Nielsen, C. J., Swietlicki, E., Putaud, J. P., Balkanski, Y., Fuzzi, S., Horth, J., Moortgat, G. K., Winterhalter, R., Myhre, C. E. L., Tsigaridis, K., Vignati, E., Stephanou, E. G., and Wilson, J.: Organic aerosol and global climate modelling: a review, Atmos. Chem. Phys., 5, 1053-1123, doi:10.5194/acp-5-1053-2005, 2005.

Keller, M., Bustamante, M., Gash, J., and Silva Dias, P. (Eds.): Geophysical Monograph Series, Volume 186, 576 pp., hardbound, ISBN 978-0-87590-476-4, AGU Code GM1864764, 2009.

Kiendler-Scharr, A., Wildt, J., Dal Maso, M., Hohaus, T., Kleist, E., Mentel, T. F., Tillmann, R., Uerlings, R., Schurr, U., and Wahner, A.: New particle formation in forests inhibited by isoprene emissions, Nature, 461, 381-384, 2009.

Kleindienst, T., Edney, E., Lewandowski, M., Offenberg, J., and Jaoui, M.: Secondary organic carbon and aerosol yields from the irradiations of isoprene and alpha-pinene in the presence of $\mathrm{NO}_{x}$ and $\mathrm{SO}_{2}$, Enviorn. Sci. Technol., 40, 3807-3812, doi:10.1021/es052446r, 2006.

Klinedinst, D. B. and Currie, L. A.: Direct quantification of PM2.5 fossil and biomass carbon within the northern front range air quality study's domain, Environ. Sci. Technol., 33, 4146-4154, 1999a.

Klinedinst, D. B. and Currie, L. A.: Direct quantification of PM2.5 fossil and biomass carbon within the Northern Front Range Air Quality Study's domain, Environ. Sci. Technol., 33, 4146-4154, 1999b.

Klouda, G. A. and Connolly, M. V.: Radiocarbon (C-14) Measurements to Quantify Sources of Atmospheric Carbon-Monoxide in Urban Air, Atmos. Environ., 29, 3309-3318, 1995.

Klouda, G. A., Lewis, C. W., Rasmussen, R. A., Rhoderick, G. C., Sams, R. L., Stevens, R. K., Currie, L. A., Donahue, D. J., Jull, A. J. T., and Seila, R. L.: Radiocarbon measurements of atmospheric volatile organic compounds: Quantifying the biogenic contribution, Environ. Sci. Technol., 30, 1098-1105, 1996.

Klouda, G. A., Lewis, C. W., Stiles, D. C., Marolf, J. L., Ellenson, W. D., and Lonneman, W. A.: Biogenic contributions to atmospheric volatile organic compounds in Azusa, California, J. Geophys. Res.-Atmos., 107, 4072, doi:10.1029/2001jc000758, 2002.

Kondo, Y., Miyazaki, Y., Takegawa, N., Miyakawa, T., Weber, R. J., Jimenez, J. L., Zhang, Q., and Worsnop, D. R.: Oxygenated and water-soluble organic aerosols in Tokyo, J. Geophys. Res.Atmos., 112, D01203, doi:10.1029/2006jd007056, 2007.

Koponen, I. K., Virkkula, A., Hillamo, R., Kerminen, V. M., and Kulmala, M.: Number size distributions and concentrations of the continental summer aerosols in Queen
Maud Land, Antarctica, J. Geophys. Res.-Atmos., 108, 4587, doi:10.1029/2003jd003614, 2003.

Kroll, J. H., Ng, N. L., Murphy, S. M., Flagan, R. C., and Seinfeld, J. H.: Secondary organic aerosol formation from isoprene photooxidation under high-NOx conditions, Geophys. Res. Lett., 32, L18808, doi:10.1029/2005g1023637, 2005.

Kroll, J. H., Ng, N. L., Murphy, S. M., Flagan, R. C., and Seinfeld, J. H.: Secondary organic aerosol formation from isoprene photooxidation, Environ. Sci. Technol., 40, 1869-1877, 2006.

Kroll, J. H. and Seinfeld, J. H.: Chemistry of secondary organic aerosol: Formation and evolution of low-volatility organics in the atmosphere, Atmos. Environ., 42, 3593-3624, 2008.

Kuang, C., McMurry, P. H., McCormick, A. V., and Eisele, F. L.: Dependence of nucleation rates on sulfuric acid vapor concentration in diverse atmospheric locations, J. Geophys. Res.-Atmos., 113, D10209, doi:10.1029/2007jd009253, 2008.

Kulmala, M., Dal Maso, M., Makela, J. M., Pirjola, L., Vakeva, M., Aalto, P., Miikkulainen, P., Hameri, K., and O’Dowd, C. D.: On the formation, growth and composition of nucleation mode particles, Tellus B, 53, 479-490, 2001.

Kulmala, M., Vehkamaki, H., Petaja, T., Dal Maso, M., Lauri, A., Kerminen, V. M., Birmili, W., and McMurry, P. H.: Formation and growth rates of ultrafine atmospheric particles: a review of observations, J. Aerosol Sci., 35, 143-176, 2004.

Kulmala, M. and Kerminen, V. M.: On the formation and growth of atmospheric nanoparticles, Atmos. Res., 90, 132-150, 2008.

Lane, T. E., Donahue, N. M., and Pandis, S. N.: Effect of $\mathrm{NO}_{\mathrm{x}}$ on secondary organic aerosol concentrations, Environ. Sci. Technol., 42, 6022-6027, 2008.

Larsen, B. R., Tudos, A., Slanina, J., Van der Borg, K., and Kotzias, D.: Quantification of airborne fossil and biomass carbonylic carbon by combined radiocarbon and liquid chromatography mass spectrometry, Atmos. Environ., 35, 5695-5707, 2001.

Lee, A., Goldstein, A. H., Kroll, J. H., Ng, N. L., Varutbangkul, V., Flagan, R. C., and Seinfeld, J. H.: Gas-phase products and secondary aerosol yields from the photooxidation of 16 different terpenes, J. Geophys. Res.-Atmos., 111, D17305, doi:10.1029/2006jd007050, 2006.

Lee, T., Sullivan, A.P., Mack, L., Jimenez, J. L., Kreidenweis, S.M. , Onasch, T. B., Worsnop, D. R., Malm, W., Wold, C. E., Hao, W. M., and Collett, J. L.: Chemical Smoke Marker Emissions During Flaming and Smoldering Phases of Laboratory Open Burning of Wildland Fuels, Aerosol Science and Technology, 44(9), i-v, doi:10.1080/02786826.2010.499884, 2010.

Lelieveld, J., Peters, W., Dentener, F. J., and Krol, M. C.: Stability of tropospheric hydroxyl chemistry, J. Geophys. Res.-Atmos., 107, 4715, doi:10.1029/2002jd002272, 2002.

Lelieveld, J., Butler, T. M., Crowley, J. N., Dillon, T. J., Fischer, H., Ganzeveld, L., Harder, H., Lawrence, M. G., Martinez, M., Taraborrelli, D., and Williams, J.: Atmospheric oxidation capacity sustained by a tropical forest, Nature, 452, 737-740, 2008.

Lemire, K. R., Allen, D. T., Klouda, G. A., and Lewis, C. W.: Fine particulate matter source attribution for Southeast Texas using C-14/C-13 ratios, J. Geophys. Res.-Atmos., 107, 4613, doi:10.1029/2002jd002339, 2002.

Lewis, C. W. and Stiles, D. C.: Radiocarbon content of PM2.5 ambient aerosol in Tampa, FL, Aerosol Sci. Technol., 40, 189-196, 2006.

Lewis, C. W., Klouda, G. A., and Ellenson, W. D.: Radiocar- 
bon measurement of the biogenic contribution to summertime PM-2.5 ambient aerosol in Nashville, TN, Atmos. Environ., 38, 6053-6061, 2004.

Liao, H. and Seinfeld, J. H.: Global impacts of gas-phase chemistryaerosol interactions on direct radiative forcing by anthropogenic aerosols and ozone, J. Geophys. Res.-Atmos., 110, D18208, doi:10.1029/2005jd005907, 2005.

Liao, H., Chen, W. T., and Seinfeld, J. H.: Role of climate change in global predictions of future tropospheric ozone and aerosols, J. Geophys. Res.-Atmos., 111, D12304, doi:10.1029/2005jd006852, 2006.

Liggio, J., Li, S.-M., and McLaren, R.: Heterogeneous Reactions of Glyoxal on Particulate Matter: Identification of Acetals and Sulfate Esters, Environ. Sci. Technol., 39(6), 1532-1541, 2005.

Lohmann, U. and Feichter, J.: Global indirect aerosol effects: a review, Atmos. Chem. Phys., 5, 715-737, doi:10.5194/acp-5-7152005, 2005.

Loukonen, V., Kurtén, T., Ortega, I. K., Vehkamäki, H., Pádua, A. A. H., Sellegri, K., and Kulmala, M.: Enhancing effect of dimethylamine in sulfuric acid nucleation in the presence of water - a computational study, Atmos. Chem. Phys., 10, 49614974, doi:10.5194/acp-10-4961-2010, 2010.

Malm, W. C., Sisler, J. F., Huffman, D., Eldred, R. A., and Cahill, T. A.: Spatial and seasonal trends in particle concentration and optical extinction in the United-States, J. Geophys. Res.-Atmos., 99, 1347-1370, 1994.

Marcolli, C., Luo, B. P., and Peter, T.: Mixing of the organic aerosol fractions: Liquids as the thermodynamically stable phases, J. Phys. Chem. A, 108(12), 2216-2224, 2004.

Mayol-Bracero, O. L., Guyon, P., Graham, B., Roberts, G., Andreae, M. O., Decesari, S., Facchini, M. C., Fuzzi, S., and Artaxo, P.: Water-soluble organic compounds in biomass burning aerosols over Amazonia - 2. Apportionment of the chemical composition and importance of the polyacidic fraction, J. Geophys. Res.-Atmos., 107, 8091, doi:10.1029/2001jd000522, 2002.

Mazzoleni, L. R., Zielinska, B., and Moosmuller, H.: Emissions of levoglucosan, methoxy phenols, and organic acids from prescribed burns, laboratory combustion of wildland fuels, and residential wood combustion, Environ. Sci. Technol., 41, 21152122, 2007.

Merikanto, J., Spracklen, D. V., Mann, G. W., Pickering, S. J., and Carslaw, K. S.: Impact of nucleation on global CCN, Atmos. Chem. Phys., 9, 8601-8616, doi:10.5194/acp-9-8601-2009, 2009.

Moffet, R. C., Qin, X. Y., Rebotier, T., Furutani, H., and Prather, K. A.: Chemically segregated optical and microphysical properties of ambient aerosols measured in a single-particle mass spectrometer, J. Geophys. Res., 113, D12213, doi:10.1029/2007jd009393, 2008.

Mönkkönen, P., Koponen, I. K., Lehtinen, K. E. J., Hämeri, K., Uma, R., and Kulmala, M.: Measurements in a highly polluted Asian mega city: observations of aerosol number size distribution, modal parameters and nucleation events, Atmos. Chem. Phys., 5, 57-66, doi:10.5194/acp-5-57-2005, 2005.

Murphy, D. M., Cziczo, D. J., Froyd, K. D., Hudson, P. K., Matthew, B. M., Middlebrook, A. M., Peltier, R. E., Sullivan, A., Thomson, D. S., and Weber, R. J.: Single-particle mass spectrometry of tropospheric aerosol particles, J. Geophys. Res., 111, D23S32, doi:10.1029/2006jd007340, 2006.
Ng, N. L., Kroll, J. H., Chan, A. W. H., Chhabra, P. S., Flagan, R. C., and Seinfeld, J. H.: Secondary organic aerosol formation from m-xylene, toluene, and benzene, Atmos. Chem. Phys., 7, 3909-3922, doi:10.5194/acp-7-3909-2007, 2007.

Nieminen, T., Manninen, H. E., Sihto, S.-L., Yli-Juuti, T., III, R. L. M., Petäjä, T., Riipinen, I., Kerminen, V. M., and Kulmala, M.: Connection of sulfuric acid to atmospheric nucleation in Boreal forest, Environ. Sci. Technol., 43(13), 4715-4721, doi:10.1021/es803152j, 2009.

Nozière, B., Ekström, S., Alsberg, T., and Holmström, S.: Radical-initiated formation of organosulfates and surfactants in atmospheric aerosols, Geophys. Res. Lett., 37, L05806, doi:10.1029/2009GL041683, 2010.

O’Dowd, C. D., Jimenez, J. L., Bahreini, R., Flagan, R. C., Seinfeld, J. H., Hameri, K., Pirjola, L., Kulmala, M., Jennings, S. G., and Hoffmann, T.: Marine aerosol formation from biogenic iodine emissions, Nature, 417, 632-636, 2002.

Odum, J. R., Hoffmann, T., Bowman, F., Collins, D., Flagan, R. C., and Seinfeld, J. H.: Gas/particle partitioning and secondary organic aerosol yields, Environ. Sci. Technol., 30, 2580-2585, 1996.

Ostro, B. and Chestnut, L.: Assessing the health benefits of reducing particulate matter air pollution in the United States, Environ. Res., 76, 94-106, 1998.

Pandis, S. N., Paulson, S. E., Seinfeld, J. H., and Flagan, R. C.: Aerosol Formation in the Photooxidation of Isoprene and BetaPinene, Atmos. Environ. Part a, 25, 997-1008, 1991.

Pankow, J. F.: An Absorption-Model of Gas-Particle Partitioning of Organic-Compounds in the Atmosphere, Atmos. Environ., 28, 185-188, 1994.

Paulot, F., Crounse, J. D., Kjaergaard, H. G., Kurten, A., St. Clair, J. M., Seinfeld, J. H., and Wennberg, P. O.: Unexpected Epoxide Formation in the Gas-Phase Photooxidation of Isoprene, Science, 325, 730-733, 2009.

Penner, J. E., Hegg, D., and Leaitch, R.: Unraveling the role of aerosols in climate change, Environ. Sci. Technol., 35, 332A340A, 2001.

Petters, M. D. and Kreidenweis, S. M.: A single parameter representation of hygroscopic growth and cloud condensation nucleus activity, Atmos. Chem. Phys., 7, 1961-1971, doi:10.5194/acp-71961-2007, 2007.

Pierce, J. R., Engelhart, G. J., Hildebrandt, L., Weitkamp, E. A., Pathak, R. K., Donahue, N. M., Robinson, A. L., Adams, P. J., and Pandis, S. N.: Constraining particle evolution from wall losses, coagulation, and condensation-evaporation in smogchamber experiments: Optimal estimation based on size distribution measurements, Aerosol Sci. Technol., 42, 1001-1015, 2008.

Pöschl, U., Martin, S. T., Sinha, B., Chen, Q., Gunthe, S. S., Huffman, J. A., Borrmann, S., Farmer, D. K., Garland, R. M., Helas, G., Jimenez, J. L., King, S. M., Manzi, A., Mikhailov, E., Pauliquevis, T., Petters, M. D., Prenni, A. J., Roldin, P., Rose, D., Schneider, J., Su, H., Zorn, S. R., Artaxo, P., and Andreae, M. O.: Rainforest Aerosols as Biogenic Nuclei of Clouds and Precipitation in the Amazon, Science, 329, 15131516, doi:10.1126/science.1191056, 2010.

Pradeep Kumar, P., Broekhuizen, K., and Abbatt, J. P. D.: Organic acids as cloud condensation nuclei: Laboratory studies of highly soluble and insoluble species, Atmos. Chem. Phys., 3, 509-520, doi:10.5194/acp-3-509-2003, 2003. 
Prenni, A. J., DeMott, P. J., Kreidenweis, S. M., Sherman, D. E., Russell, L. M., and Ming, Y.: The effects of low molecular weight dicarboxylic acids on cloud formation, J. Phys. Chem. A, 105, 11240-11248, 2001.

Prenni, A. J., De Mott, P. J., and Kreidenweis, S. M.: Water uptake of internally mixed particles containing ammonium sulfate and dicarboxylic acids, Atmos. Environ., 37, 4243-4251, 2003.

Prenni, A. J., Petters, M. D., DeMott, P. J., Kreidenweis, S. M., Ziemann, P. J., Matsunaga, A., and Lim, Y. B.: Cloud drop activation of secondary organic aerosol, J. Geophys. Res., 112, D10223, doi:10.1029/2006jd007963, 2007.

Presto, A. A., Hartz, K. E. H., and Donahue, N. M.: Secondary organic aerosol production from terpene ozonolysis. 2. Effect of $\mathrm{NO}_{\mathrm{x}}$ concentration, Environ. Sci. Technol., 39, 7046-7054, 2005.

Prisle, N. L., Engelhart, G. J., Bilde, M., and Donahue, N. M.: Humidity influence on gas-particle phase partitioning of alphapinene + O-3 secondary organic aerosol, Geophys. Res. Lett., 37, L01802, doi:10.1029/2009g1041402, 2010.

Rasmussen, R. A. and Khalil, M. A. K.: Isoprene over the Amazon Basin, J. Geophys. Res.-Atmos., 93, 1417-1421, 1988.

Raymond, T. M. and Pandis, S. N.: Cloud activation of singlecomponent organic aerosol particles, J. Geophys. Res.-Atmos., 107, 4787, doi:10.1029/2002jd002159, 2002.

Rizzo, L. V., Artaxo, P., Karl, T., Guenther, A. B., and Greenberg, J.: Aerosol properties, in-canopy gradients, turbulent fluxes and VOC concentrations at a pristine forest site in Amazonia, Atmos. Environ., 44, 503-511, 2010.

Roberts, G. C., Artaxo, P., Zhou, J. C., Swietlicki, E., and Andreae, M. O.: Sensitivity of CCN spectra on chemical and physical properties of aerosol: A case study from the Amazon Basin, J. Geophys. Res.-Atmos., 107, 8070, doi:10.1029/2001jd000583, 2002.

Robinson, A. L., Subramanian, R., Donahue, N. M., BernardoBricker, A., and Rogge, W. F.: Source apportionment of molecular markers and organic aerosol. 2. Biomass smoke, Environ. Sci. Technol., 40, 7811-7819, 2006.

Robinson, A. L., Donahue, N. M., Shrivastava, M. K., Weitkamp, E. A., Sage, A. M., Grieshop, A. P., Lane, T. E., Pierce, J. R., and Pandis, S. N.: Rethinking organic aerosols: Semivolatile emissions and photochemical aging, Science, 315, 1259-1262, 2007.

Sakurai, H., Tobias, H. J., Park, K., Zarling, D., Docherty, K. S., Kittelson, D. B., McMurry, P. H., and Ziemann, P. J.: On-line measurements of diesel nanoparticle composition and volatility, Atmos. Environ., 37, 1199-1210, 2003.

Salcedo, D., Onasch, T. B., Dzepina, K., Canagaratna, M. R., Zhang, Q., Huffman, J. A., DeCarlo, P. F., Jayne, J. T., Mortimer, P., Worsnop, D. R., Kolb, C. E., Johnson, K. S., Zuberi, B., Marr, L. C., Volkamer, R., Molina, L. T., Molina, M. J., Cardenas, B., Bernabé, R. M., Márquez, C., Gaffney, J. S., Marley, N. A., Laskin, A., Shutthanandan, V., Xie, Y., Brune, W., Lesher, R., Shirley, T., and Jimenez, J. L.: Characterization of ambient aerosols in Mexico City during the MCMA-2003 campaign with Aerosol Mass Spectrometry: results from the CENICA Supersite, Atmos. Chem. Phys., 6, 925-946, doi:10.5194/acp-6-9252006, 2006.

Schauer, J. J. and Cass, G. R.: Source apportionment of wintertime gas-phase and particle-phase air pollutants using organic compounds as tracers, Environ. Sci. Technol., 34, 1821-1832, 2000.
Schauer, J. J., Fraser, M. P., Cass, G. R., and Simoneit, B. R. T.: Source reconciliation of atmospheric gas-phase and particlephase pollutants during a severe photochemical smog episode, Environ. Sci. Technol., 36, 3806-3814, 2002.

Schichtel, B. A., Malm, W. C., Bench, G., Fallon, S., McDade, C. E., Chow, J. C., and Watson, J. G.: Fossil and contemporary fine particulate carbon fractions at 12 rural and urban sites in the United States, J. Geophys. Res.-Atmos., 113, D02311, doi:10.1029/2007jd008605, 2008.

Schulz, M., Textor, C., Kinne, S., Balkanski, Y., Bauer, S., Berntsen, T., Berglen, T., Boucher, O., Dentener, F., Guibert, S., Isaksen, I. S. A., Iversen, T., Koch, D., Kirkevåg, A., Liu, X., Montanaro, V., Myhre, G., Penner, J. E., Pitari, G., Reddy, S., Seland, Ø., Stier, P., and Takemura, T.: Radiative forcing by aerosols as derived from the AeroCom present-day and pre-industrial simulations, Atmos. Chem. Phys., 6, 5225-5246, doi:10.5194/acp-6-5225-2006, 2006.

Seinfeld, J. H. and Pandis, S. N.: Atmospheric Chemistry and Physics - From Air Pollution to Climate Change (2nd Edition), John Wiley \& Sons, 1998.

Seinfeld, J. H. and Pankow, J. F.: Organic atmospheric particulate material. Ann. Rev. Phys. Chem., 54, 121-140, 2003.

Seinfeld, J. H., Erdakos, G. B., Asher, W. E., and Pankow, J. F.: Modeling the formation of secondary organic aerosol (SOA). 2. The predicted effects of relative humidity on aerosol formation in the alpha-pinene-, beta-pinene-, sabinene-, Delta(3)-Carene, and cyclohexene-ozone systems, Environ. Sci. Technol., 35, 1806-1817, 2001.

Shrivastava, M. K., Subramanian, R., Rogge, W. F., and Robinson, A. L.: Sources of organic aerosol: Positive matrix factorization of molecular marker data and comparison of results from different source apportionment models, Atmos. Environ., 41, 93539369, 2007.

Sipila, M., Berndt, T., Petaja, T., Brus, D., Vanhanen, J., Stratmann, F., Patokoski, J., Mauldin, R. L., Hyvarinen, A. P., Lihavainen, H., and Kulmala, M.: The Role of Sulfuric Acid in Atmospheric Nucleation, Science, 327, 1243-1246, 2010.

Smith, J. N., Dunn, M. J., VanReken, T. M., Iida, K., Stolzenburg, M. R., McMurry, P. H., and Huey, L. G.: Chemical composition of atmospheric nanoparticles formed from nucleation in Tecamac, Mexico: Evidence for an important role for organic species in nanoparticle growth, Geophys. Res. Lett., 35, L04808, doi:10.1029/2007g1032523, 2008.

Song, C., Zaveri, R. A., Alexander, M. L., Thornton, J. A., Madronich, S., Ortega, J. V., Zelenyuk, A., Yu, X. Y., Laskin, A., and Maughan, D. A.: Effect of hydrophobic primary organic aerosols on secondary organic aerosol formation from ozonolysis of alpha-pinene, Geophys. Res. Lett., 34, L20803, doi:10.1029/2007g1030720, 2007.

Stolzenburg, M. R., McMurry, P. H., Sakurai, H., Smith, J. N., Mauldin, R. L., Eisele, F. L., and Clement, C. F.: Growth rates of freshly nucleated atmospheric particles in Atlanta, J. Geophys. Res.-Atmos., 110, D22s05, doi:10.1029/2005jd005935, 2005.

Sullivan, A. P., Weber, R. J., Clements, A. L., Turner, J. R., Bae, M. S., and Schauer, J. J.: A method for on-line measurement of water-soluble organic carbon in ambient aerosol particles: Results from an urban site, Geophys. Res. Lett., 31, L13105, doi:10.1029/2004g1019681, 2004.

Sullivan, A. P., Holden, A. S., Patterson, L. A., McMeeking, G. 
R., Kreidenweis, S. M., Malm, W. C., Hao, W. M., Wold, C. E., and Collett, J. L.: A method for smoke marker measurements and its potential application for determining the contribution of biomass burning from wildfires and prescribed fires to ambient PM2.5 organic carbon, J. Geophys. Res.-Atmos., 113, D22302, doi:10.1029/2008JD010216, 2008.

Sun, J. Y., Zhang, Q., Canagaratna, M. R., Zhang, Y. M., Ng, N. L., Sun, Y. L., Jayne, J. T., Zhang, X. C., Zhang, X. Y., and Worsnop, D. R.: Highly time- and size-resolved characterization of submicron aerosol particles in Beijing using an Aerodyne Aerosol Mass Spectrometer, Atmos. Environ., 44, 131-140, 2010.

Surratt, J. D., Murphy, S. M., Kroll, J. H., Ng, L. N., Hildebrandt, L., Sorooshian, A., Szmigielski, R., Vermeylen, R., Maenhaut, W., Claeys, M., Flagan, R. C., and Seinfeld, J. H.: Chemical composition of secondary organic aerosol formed from the photooxidation of isoprene, J. Phys. Chem. A, 110, 9665-9690, doi:10.1021/jp061734m, 2006.

Surratt, J. D., Lewandowski, M., Offenberg, J. H., Jaoui, M., Kleindienst, T. E., Edney, E. O., and Seinfeld, J. H.: Effect of acidity on secondary organic aerosol formation from isoprene, Environ. Sci. Technol., 41, 5363-5369, doi:10.1021/es0704176, 2007.

Surratt, J. D., Gomez-Gonzalez, Y., Chan, A. W. H., Vermeylen, R., Shahgholi, M., Kleindienst, T. E., Edney, E. O., Offenberg, J. H., Lewandowski, M., Jaoui, M., Maenhaut, W., Claeys, M., Flagan, R. C., and Seinfeld, J. H.: Organosulfate formation in biogenic secondary organic aerosol, J. Phys. Chem. A, 112, 8345-8378, 2008.

Surratt, J. D., Chan, A. W. H., Eddingsaas, N. A. Chan, M. N., Loza, C. L., Kwan, A. J., Hersey, S. P., Flagan, R. C., Wennberg, P. O., and Seinfeld, J. H.: Reactive intermediates revealed in secondary organic aerosol formation from isoprene, P. Natl. Acad. Sci. USA, 107, 6640-6645, doi:10.1073/pnas.0911114107, 2010.

Szidat, S., Jenk, T. M., Gaggeler, H. W., Synal, H. A., Fisseha, R., Baltensperger, U., Kalberer, M., Samburova, V., Reimann, S., Kasper-Giebl, A., and Hajdas, I.: Radiocarbon (C-14)-deduced biogenic and anthropogenic contributions to organic carbon (OC) of urban aerosols from Zurich, Switzerland, Atmos. Environ., 38, 4035-4044, 2004.

Szidat, S., Jenk, T. M., Synal, H. A., Kalberer, M., Wacker, L., Hajdas, I., Kasper-Giebl, A., and Baltensperger, U.: Contributions of fossil fuel, biomass-burning, and biogenic emissions to carbonaceous aerosols in Zurich as traced by C-14, J. Geophys. Res.-Atmos., 111, D07206, doi:10.1029/2005jd006590, 2006.

Szidat, S., Ruff, M., Perron, N., Wacker, L., Synal, H.-A., Hallquist, M., Shannigrahi, A. S., Yttri, K. E., Dye, C., and Simpson, D.: Fossil and non-fossil sources of organic carbon (OC) and elemental carbon (EC) in Gteborg, Sweden, Atmos. Chem. Phys., 9, 1521-1535, doi:10.5194/acp-9-1521-2009, 2009.

Takahama, S., Davidson, C. I., and Pandis., S. N.: Semicontinuous Measurements of Organic Carbon and Acidity during the Pittsburgh Air Quality Study: Implications for Acid-Catalyzed Organic Aerosol Formation, Environ. Sci. Technol., 40(7), 21912199, 2006.

Takahashi, K., Hirabayashi, M., Tanabe, K., Shibata, Y., Nishikawa, M., and Sakamoto, K.: Radiocarbon content in urban atmospheric aerosols, Water Air Soil Pollut., 185, 305-310, 2007.

Tanner, R. L. and Parkhurst, W.: Chemical Composition of Fine Particles in the Tennessee Valley Region, J. Air Waste Manage. Assoc., 50, 1299-1307, 2000.
Thornton, J. A., Wooldridge, P. J., Cohen, R. C., Martinez, M., Harder, H., Brune, W. H., Williams, E. J., Roberts, J. M., Fehsenfeld, F. C., Hall, S. ., Shetter, R. E., Wert, B. P., and Fried, A.: Ozone production rates as a function of NOx abundances and HOx production rates in the Nashville urban plume, J. Geophys. Res.-Atmos., 107, 4146, doi:10.1029/2001jd000932, 2002.

Tsigaridis, K. and Kanakidou, M.: Global modelling of secondary organic aerosol in the troposphere: a sensitivity analysis, Atmos. Chem. Phys., 3, 1849-1869, doi:10.5194/acp-3-1849-2003, 2003.

Tsigaridis, K. and Kanakidou, M.: Secondary organic aerosol importance in the future atmosphere, Atmos. Environ., 41, 46824692, 2007.

Tsigaridis, K., Lathière, J., Kanakidou, M., and Hauglustaine, D. A.: Naturally driven variability in the global secondary organic aerosol over a decade, Atmos. Chem. Phys., 5, 1891-1904, doi:10.5194/acp-5-1891-2005, 2005.

Tsigaridis, K., Krol, M., Dentener, F. J., Balkanski, Y., Lathière, J., Metzger, S., Hauglustaine, D. A., and Kanakidou, M.: Change in global aerosol composition since preindustrial times, Atmos. Chem. Phys., 6, 5143-5162, doi:10.5194/acp-6-5143-2006, 2006.

Tunved, P., Hansson, H. C., Kerminen, V. M., Strom, J., Dal Maso, M., Lihavainen, H., Viisanen, Y., Aalto, P. P., Komppula, M., and Kulmala, M.: High natural aerosol loading over boreal forests, Science, 312, 261-263, 2006.

Twomey, S.: Pollution and Planetary Albedo, Atmos. Environ., 8, 1251-1256, 1974.

Twomey, S. A., Piepgrass, M., and Wolfe, T. L.: An Assessment of the Impact of Pollution on Global Cloud Albedo, Tellus B, 36, 356-366, 1984.

VanReken, T. M., Greenberg, J. P., Harley, P. C., Guenther, A. B., and Smith, J. N.: Direct measurement of particle formation and growth from the oxidation of biogenic emissions, Atmos. Chem. Phys., 6, 4403-4413, doi:10.5194/acp-6-4403-2006, 2006.

Varutbangkul, V., Brechtel, F. J., Bahreini, R., Ng, N. L., Keywood, M. D., Kroll, J. H., Flagan, R. C., Seinfeld, J. H., Lee, A., and Goldstein, A. H.: Hygroscopicity of secondary organic aerosols formed by oxidation of cycloalkenes, monoterpenes, sesquiterpenes, and related compounds, Atmos. Chem. Phys., 6, 23672388, doi:10.5194/acp-6-2367-2006, 2006.

Weber, R. J., Marti, J. J., McMurry, P. H., Eisele, F. L., Tanner, D. J., and Jefferson, A.: Measured atmospheric new particle formation rates: Implications for nucleation mechanisms, Chemical Engineering Communications, 151, 53-64, 1996.

Weber, R. J., Sullivan, A. P., Peltier, R. E., Russell, A., Yan, B., Zheng, M., de Gouw, J., Warneke, C., Brock, C., Holloway, J. S., Atlas, E. L., and Edgerton, E.: A study of secondary organic aerosol formation in the anthropogenic-influenced southeastern United States, J. Geophys. Res.-Atmos., 112, D13302, doi:10.1029/2007jd008408, 2007.

Wehner, B., Petaja, T., Boy, M., Engler, C., Birmili, W., Tuch, T., Wiedensohler, A., and Kulmala, M.: The contribution of sulfuric acid and non-volatile compounds on the growth of freshly formed atmospheric aerosols, Geophys. Res. Lett., 32, L17810, doi:10.1029/2005g1023827, 2005.

Yin, J. X., Harrison, R. M., Chen, Q., Rutter, A., and Schauer, J. J.: Source apportionment of fine particles at urban background and rural sites in the UK atmosphere, Atmos. Environ., 44, 841-851, 
2010.

Yu, F. and Luo, G.: Simulation of particle size distribution with a global aerosol model: contribution of nucleation to aerosol and CCN number concentrations, Atmos. Chem. Phys., 9, 76917710, doi:10.5194/acp-9-7691-2009, 2009.

Zhang, J. Y., Hartz, K. E. H., Pandis, S. N., and Donahue, N. M.: Secondary organic aerosol formation from limonene ozonolysis: Homogeneous and heterogeneous influences as a function of NOx, J. Phys. Chem. A, 110, 11053-11063, 2006.

Zhang, Q., Stanier, C. O., Canagaratna, M. R., Jayne, J. T., Worsnop, D. R., Pandis, S. N., and Jimenez, J. L., Insights into the chemistry of new particle formation and growth events in Pittsburgh based on aerosol mass spectrometry, Environ. Sci. Technol., 38, 4797-4809, doi:10.1021/es035417u, 2004.

Zhang, Q., Alfarra, M. R., Worsnop, D. R., Allan, J. D., Coe, H., Canagaratna, M. R., and Jimenez, J. L.: Deconvolution and quantification of hydrocarbon-like and oxygenated organic aerosols based on aerosol mass spectrometry, Environ. Sci. Technol., 39, 4938-4952, 2005a.

Zhang, Q., Worsnop, D. R., Canagaratna, M. R., and Jimenez, J. L.: Hydrocarbon-like and oxygenated organic aerosols in Pittsburgh: insights into sources and processes of organic aerosols, Atmos. Chem. Phys., 5, 3289-3311, doi:10.5194/acp-5-32892005, 2005b.
Zhang, Q., Jimenez, J. L., Canagaratna, M. R., Allan, J. D., Coe, H., Ulbrich, I., Alfarra, M. R., Takami, A., Middlebrook, A. M., Sun, Y. L., Dzepina, K., Dunlea, E., Docherty, K., DeCarlo, P. F., Salcedo, D., Onasch, T., Jayne, J. T., Miyoshi, T., Shimono, A., Hatakeyama, S., Takegawa, N., Kondo, Y., Schneider, J., Drewnick, F., Borrmann, S., Weimer, S., Demerjian, K., Williams, P., Bower, K., Bahreini, R., Cottrell, L., Griffin, R. J., Rautiainen, J., Sun, J. Y., Zhang, Y. M., and Worsnop, D. R.: Ubiquity and dominance of oxygenated species in organic aerosols in anthropogenically-influenced Northern Hemisphere midlatitudes, Geophys. Res. Lett., 34, L13801, doi:10.1029/2007g1029979, 2007a.

Zhang, Q., Jimenez, J. L., Worsnop, D. R., and Canagaratna, M.: Case Study of Urban Particle Acidity and Its Influence on Secondary Organic Aerosol, Environ. Sci. Technol., 41 (9), 3213 3219, $2007 b$.

Zheng, M., Cass, G. R., Schauer, J. J., and Edgerton, E. S.: Source apportionment of PM2.5 in the Southeastern United States using solvent-extractable organic compounds as tracers, Environ. Sci. Technol., 36, 2361-2371, 2002. 